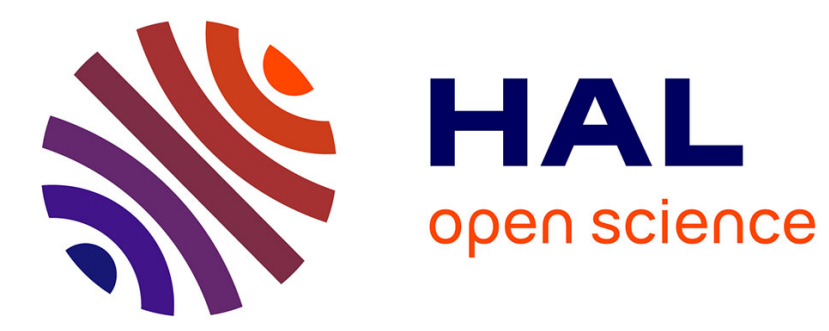

\title{
Synthesis and structure of ruthenium-fullerides
}

Faqiang Leng, I.C. Gerber, Pierre Lecante, Wolfgang Bacsa, J. Miller, J.R.

Gallagher, S. Moldovan, M. Girleanu, M.R. Axet, Philippe Serp

\section{To cite this version:}

Faqiang Leng, I.C. Gerber, Pierre Lecante, Wolfgang Bacsa, J. Miller, et al.. Synthesis and structure of ruthenium-fullerides. RSC Advances, 2016, 6 (73), pp.69135-69148. 10.1039/c6ra12023g . hal01757293

\section{HAL Id: hal-01757293 \\ https://hal.science/hal-01757293}

Submitted on 3 Apr 2018

HAL is a multi-disciplinary open access archive for the deposit and dissemination of scientific research documents, whether they are published or not. The documents may come from teaching and research institutions in France or abroad, or from public or private research centers.
L'archive ouverte pluridisciplinaire HAL, est destinée au dépôt et à la diffusion de documents scientifiques de niveau recherche, publiés ou non, émanant des établissements d'enseignement et de recherche français ou étrangers, des laboratoires publics ou privés. 
(2) CrossMark

Cite this: RSC Adv., 2016, 6, 69135

Received 9th May 2016

Accepted 14th July 2016

DOI: 10.1039/c6ra12023g

www.rsc.org/advances

\section{Synthesis and structure of ruthenium-fullerides $\uparrow$}

\author{
F. Leng, ${ }^{a b}$ I. C. Gerber, ${ }^{c}$ P. Lecante, ${ }^{d}$ W. Bacsa, ${ }^{d}$ J. Miller, ${ }^{e}$ J. R. Gallagher, \\ S. Moldovan, ${ }^{f}$ M. Girleanu, ${ }^{\text {fg }}$ M. R. Axet ${ }^{\star a b}$ and P. Serp ${ }^{\star a b}$
}

We report a simple and original procedure for preparing $\mathrm{Ru}-\mathrm{C}_{60}$ polymeric chains, which spontaneously self-assemble as polymeric spherical particles. The size of the particles can be controlled by the choice of the solvent used during the reaction. In addition, these $\mathrm{Ru}-\mathrm{C}_{60}$ polymeric spheres can be surface decorated with Ru nanoparticles using the same mild reaction conditions by changing the $\mathrm{Ru} / \mathrm{C}_{60}$ ratio. Several techniques (TEM in high resolution, scanning and electron tomography modes, IR, NMR, Raman, WAXS, EXAFS and XPS) together with theoretical calculations allowed us to have an insight into the structure of these $\mathrm{Ru}-\mathrm{C}_{60}$ species.

\section{Introduction}

Extensive investigations of fullerene $\mathrm{C}_{60}$, both in its pristine form as well as in its doped or intercalated variants, have definitively confirmed a strong tendency toward polymerization of this molecule. ${ }^{1}$ The combination of $\mathrm{C}_{60}$ and metals offer exciting perspectives for the production of novel fullerenebased architectures with unprecedented properties for catalysis, ${ }^{2-4}$ batteries, ${ }^{5}$ sensors ${ }^{6}$ or nanoelectronic devices. ${ }^{7}$ Indeed, the spherical shape, high degree of symmetry, and coordinating geometries of $\mathrm{C}_{60}$ make it an ideal candidate for the construction of well-defined supramolecular architectures. The metal fullerides have been the subject of intensive investigations over the past 20 years, and mostly compounds of $\mathrm{C}_{60}$ with alkali and alkaline metals $\left(\mathrm{A}-\mathrm{C}_{60}\right)$ have been synthesized. ${ }^{8}$ Metals in these compounds usually occupy interstitial sites in the octahedral or tetrahedral environment of the $\mathrm{C}_{60}$ structure. The bonding in these fullerides is ionic and the $\mathrm{C}_{60}$ molecules rotate freely. $\mathrm{Li}_{4} \mathrm{C}_{60}$, one of the most characteristic representatives of lithium intercalated fullerides, features an unusual type of two-

${ }^{a}$ CNRS, LCC (Laboratoire de Chimie de Coordination), Composante ENSIACET, 4 allée Emile Monso, BP 44099, F-31030 Toulouse Cedex 4, France. E-mail: philippe.serp@ ensiacet.fr; rosa.axet@lcc-toulouse.fr

${ }^{b}$ Université de Toulouse, UPS, INPT, F-31077 Toulouse Cedex 4, France

'Université de Toulouse, INSA, UPS, CNRS, LPCNO (IRSAMC), 135 avenue de Rangueil, F-31077 Toulouse, France

${ }^{d}$ Centre d'élaboration des Matériaux et d'études Structurales UPR CNRS 8011, 29 Rue Jeanne-Marvig, BP 4347, 31055 Toulouse, France

${ }^{e}$ Argonne National Laboratory, Chemical Sciences and Engineering Division, $9700 \mathrm{~S}$. Cass Ave, Building 200, Argonne, IL 60429-4837, USA

IInstitut de Physique et Chimie des Matériaux de Strasbourg, UMR 7504 CNRS-UdS, 23 rue du Loess BP43, 67034 Strasbourg Cedex 2, France

IInstitut de Recherche Biomédicales des Armées, Unité Imagerie, Place du Médecin Général Inspecteur Valérie André, BP73, 91220 Brétigny-sur-Orge, France

$\dagger$ Electronic supplementary information (ESI) available. See DOI: $10.1039 / \mathrm{c} 6 \mathrm{ra12023g}$ dimensional polymerization. ${ }^{9}$ In contrast, only a few reports claiming the existence of fullerides with transition metals (TM) are known; ${ }^{10}$ and despite the progress in study of $\mathrm{A}-\mathrm{C}_{60}$ polymerization, ${ }^{11,12}$ the knowledge about this phenomenon in the TM- $\mathrm{C}_{60}$ systems is scarce. Transition metal fullerides can be prepared by chemical reactions in solution between a suitable TM complex and $\mathrm{C}_{60},{ }^{13}$ through electrochemical reduction from solutions of $\mathrm{C}_{60}$ and selected $\mathrm{TM}$ complexes, ${ }^{14}$ or by coevaporation of TM and $\mathrm{C}_{60}$ from separate sources under ultrahigh vacuum (UHV) conditions. ${ }^{15}$ Up to now, TM fullerides of $\mathrm{Pd},{ }^{13} \mathrm{Pt},{ }^{16} \mathrm{Co},{ }^{17} \mathrm{Ru},{ }^{18} \mathrm{Fe},{ }^{19} \mathrm{Rh},{ }^{20}$ and $\mathrm{Ti}^{15}$ have been reported. Although an understanding of the structure and bonding of the proposed compounds is highly desirable, the structure of these phases is still under discussion due to the poor crystallinity of the obtained samples. Depending on the amount of metal the suggested structure could be polymeric with a chain-like, twoor three-dimensional coordination. Moreover, it is believed that metal atoms serve as bridges connecting neighboring $\mathrm{C}_{60}$ molecules.

The first and the most studied, TM fulleride, $\mathrm{Pd}_{x}-\mathrm{C}_{60}$, was reported in 1992 by Nagashima et al. ${ }^{13}$ This compounds, insoluble in most organic solvents, precipitated by mixing $\left[\mathrm{Pd}_{2}(\mathrm{dba})_{3}\right](\mathrm{dba}=$ dibenzylideneacetone $)$ and $\mathrm{C}_{60}$ benzene solutions at room temperature. Two and three-dimensional amorphous polymeric structures were already proposed based on the results of electron probe microanalysis for $\mathrm{Pd}_{x}-\mathrm{C}_{60}$, but the exact nature of these polymers remains really unclear. Additionally, various TEM studies on the $\mathrm{Pd}_{x}-\mathrm{C}_{60}$ compound suggest the possible presence of Pd nanoparticles (NPs) in the material. $^{21-23}$ The presence of metallic clusters was also evidenced for $\mathrm{Ru}_{x}-\mathrm{C}_{60}$ compounds produced at higher temperatures from $\left[\mathrm{Ru}_{3}(\mathrm{CO})_{12}\right]^{18,24}$ However, using TEM, Lavrentiev et al. have observed the polymeric chains in the $\mathrm{Co}_{x}-\mathrm{C}_{60}$ mixture, which inner structure has been evaluated as $\left(-\mathrm{C}_{60}-\mathrm{Co}-\right.$ $\mathrm{C}_{60^{-}}$) order. ${ }^{25}$ It is worth mentioning that most of these structural studies have used a single characterization techniques 
such as Raman spectroscopy, ${ }^{19}$ XPS, ${ }^{15}$ or TEM. ${ }^{21}$ Some theoretical works, using Density Functional Theory (DFT), on exohedral fullerenes have been mainly devoted to the interaction between $\mathrm{C}_{60}$ and alkali atoms: $\mathrm{Na}, \mathrm{K}^{26-29}$ and in a lesser extent $\mathrm{TM}$, mainly $\mathrm{V},{ }^{30} \mathrm{Ni},{ }^{31} \mathrm{Au}^{32,33}$ and $\mathrm{Ta}^{34,35}$ and more recently with $\mathrm{Pd}$ and Pt atoms. ${ }^{36}$ To our knowledge, no theoretical studies on the existence or the possible structures of $-\mathrm{C}_{60}-\mathrm{TM}-\mathrm{C}_{60}-$ linear chains have been reported.

Considering the possible applications of these supramolecular architectures, it is important to have a better knowledge of their structure for the establishment of structure/properties relationships. In this context, we decided to reexamine the structure of such compounds in the case of ruthenium with a large variety of complementary characterization techniques, including TEM in high resolution, scanning and electron tomography modes, IR, NMR, Raman, WAXS, EXAFS and XPS, as well as DFT calculations. The combination of all these techniques allowed us to propose that $-\mathrm{C}_{60}-\mathrm{Ru}-\mathrm{C}_{60}-$ polymers are formed and that $\mathrm{Ru}$ exhibits a $\eta^{2(6)}-\eta^{6}$ coordination mode. In addition, the control of the reaction conditions allows us to synthesize $\mathrm{C}_{60}-\mathrm{Ru}-\mathrm{C}_{60}-$ polymers, nanospherical $\mathrm{Ru}-\mathrm{C}_{60}$ polymers, $\mathrm{Ru}$ Nps decorated nanospherical $\mathrm{Ru}-\mathrm{C}_{60}$ polymers, and $\mathrm{Ru}$ nanoparticles supported on a $\mathrm{C}_{60}$ matrix.

\section{Experimental section}

\subsection{General methods}

All operations were carried out under argon atmosphere using standard Schlenk techniques or in an MBraun glovebox. Solvents were purified by standard methods or by an MBraun SPS-800 solvent purification system. [Ru(COD)(COT)] was purchased from Nanomeps Toulouse, fullerene $\mathrm{C}_{60}$ from SigmaAldrich, $\mathrm{CO}$ and $\mathrm{H}_{2}$ from Air Liquide. All these reactants were used as received.

The ruthenium content was established by inductively coupled plasma optical emission spectroscopy (ICP-OES) in a Thermo Scientific ICAP 6300 instrument. Solid state NMR (MAS-NMR) with and without ${ }^{1} \mathrm{H}^{-13} \mathrm{C}$ cross polarization (CP) were performed on a Bruker Avance 400WB instrument equipped with a $4 \mathrm{~mm}$ probe with the sample rotation frequency being set at $12 \mathrm{kHz}$ unless otherwise indicated. Measurements were carried out in a $4 \mathrm{~mm} \mathrm{ZrO}_{2}$ rotor. ATR-IR spectra were recorded on a Perkin-Elmer GX2000 spectrometer available in a glovebox, in the range $4000-400 \mathrm{~cm}^{-1}$. The Raman spectra have been recorded with a Explora (Horiba) spectrometer in backscattering geometry using an optical objective $\times 100$ (NA 0.9 ). The wavelength of the incident laser has been $532 \mathrm{~nm}$ and the laser power was set to $1 \mathrm{~mW}$.

\subsection{TEM analyses}

Some TEM and HRTEM analyses were performed by using a JEOL JEM 1011 CX-T electron microscope operating at $100 \mathrm{kV}$ with a point resolution of $4.5 \AA$ and a JEOL JEM 1400 electron microscope operating at $120 \mathrm{kV}$. The high resolution analyses were conduct using a JEOL JEM 2100F equipped with a Field Emission Gun (FEG) operating at $200 \mathrm{kV}$ with a point resolution of $2.3 \AA$ and a JEOL JEM-ARM200F Cold FEG operating at $200 \mathrm{kV}$ with a point resolution of $>1.9 \AA$. The approximation of the particles mean size was made through a manual analysis of enlarged micrographs by measuring at least 200 particles on a given grid. Other TEM micrographs were acquired with a JEOL 2100F S/TEM microscope equipped with a FEG operating at $200 \mathrm{kV}$, a spherical aberration probe corrector and a GATAN Tridiem energy filter. The resolutions attained are $2 \AA$ and $1.1 \AA$ under parallel TEM mode and scanning STEM modes, respectively. For STEM-HAADF analyses the spot size was of $0.13 \mathrm{~nm}$, a current density of $140 \mathrm{pA}$, the camera focal length was $10 \mathrm{~cm}$, corresponding to inner and outer detection angle of the annular detector of about $60 \mathrm{mrad}$ and 160 mrad. For tomography experiments, the acquisitions of the tilt images series were performed using a high tilt sample holder, under angles spanning from +72 to $-72^{\circ}$, with projections taken every $2^{\circ}$ according to Saxton scheme. The irradiation damage was limited by using low electron doses. The images were first roughly aligned using a cross-correlation algorithm. A refinement of this initial alignment and a precise determination of the tilt axis direction were then obtained using the IMOD software where the centers of several Au nanoparticles from the analyzed group were used as fiducial markers. ${ }^{37}$ The volume reconstructions have been computed using an iterative approach consisting of a simultaneous algebraic reconstruction technique implemented using the TOMO3D software, ${ }^{38}$ the number of iterations not exceeding 40 . Visualization and quantitative analysis of the final volumes were carried out using ImageJ software.

\subsection{DFT calculations}

DFT calculations were carried out using the Vienna ab initio simulation package VASP. ${ }^{39-42}$ The code uses the full-potential projector augmented wave (PAW) framework. ${ }^{43,44}$ Exchangecorrelation effects have been approximated using the PBE functional ${ }^{\mathbf{4 5}}$ and applied in spin-polarized calculations. Besides to correctly describe weak intermolecular forces between $\mathrm{Ru}-$ $\mathrm{C}_{60}$ complexes and solvent molecules, we have also used the optB86b-vdW functional. ${ }^{46-49}$ We have checked that this scheme provide accurate geometries when van der Waals forces are the major bonding origin, as for instance in the $\mathrm{C}_{60}$ crystalline phase. See ESI.15 $\uparrow$ for the direct comparison between simulated and experimental WAXS spectra. If a slight compression factor of $1.5 \%$ is applied on the DFT structure, the agreement becomes almost perfect between peaks up to $0.8 \mathrm{~nm}$. A kinetic-energy cutoff of $400 \mathrm{eV}$ was found to be sufficient to achieve a totalenergy convergence within several $\mathrm{meV}$, considering a $k$-point sampling with a $(1 \times 1 \times 5)$ grid for the polymeric state or gamma-point only calculations for isolated molecules and complexes, in conjunction with a Gaussian smearing with a width of $0.05 \mathrm{eV}$. During geometry optimization runs and cell relaxations, all the atoms were fully relaxed until forces on

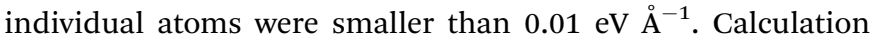
cells for isolated molecules and complexes were $25 \times 26 \times 27 \AA$, to avoid spurious interactions between periodic images, when the same lattice parameters on (Ox) and (Oy) were kept fixed for the polymeric phase. Figures of the different geometries were produced thanks to the $3 \mathrm{D}$ visualization program VESTA. ${ }^{50}$ 


\subsection{WAXS, EXAFS, and XPS analyses}

Wide angle X-ray scattering measurements were performed on a diffractometer dedicated to Pair Distribution Function (PDF) analysis: graphite-monochromatized molybdenum radiation $(0.07169 \mathrm{~nm})$, solid state detection and low background setup. Samples were sealed in Lindemann glass capillaries (diameter $1.5 \mathrm{~mm}$ ) to avoid any oxidation after filling in a glove box. For all samples data were collected on an extended angular range (129 degrees in 2 theta) with counting times of typically $150 \mathrm{~s}$ for each of the 457 data points, thus allowing for PDF analysis. Classic corrections (polarization and absorption in cylindrical geometry) were applied before reduction and Fourier transform.

X-ray absorption measurements were made on the bending magnet beam line of the Materials Research Collaborative Access Team (MRCAT) at the Advanced Photon Source, Argonne National Laboratory. The data were collected in step-scan, transmission mode. The 3 pre-edge regions, from -250 to $-50 \mathrm{eV},-50$ to $-10 \mathrm{eV}$ and -10 to $30 \mathrm{eV}$, were scanned in 10,5 and $0.4 \mathrm{eV}$ steps, respectively. The EXAFS was also scanned in 3 regions, to 6 , from $6-10$ and from $10-13 \AA^{-1}$. The data acquisition time in each region was increased to give a high signal to noise in the $k^{2}$-weighted chi. The $\mathrm{Ru}$ on $\mathrm{C}_{60}$ samples were handled and loaded in the absence of air and water in a glove box. The samples were placed in an environmental cell for data acquisition. The samples were additionally treated in $4 \% \mathrm{H}_{2} / \mathrm{He}$ at $150{ }^{\circ} \mathrm{C}$, cooled to room temperature and data taken without exposure to air. A ruthenium foil spectrum was acquired simultaneously with each measurement for energy calibration. Samples were pressed into a cylindrical holder capable of holding 6 samples with amounts chosen to give a ruthenium edge step of $c a$. 0.5-1.0. The spectra were obtained at room temperature without treatment and after heating in $4 \% \mathrm{H}_{2} / \mathrm{He}$ at $150{ }^{\circ} \mathrm{C}$ for $1 \mathrm{~h}$ and cooled to RT. $\mathrm{RuO}_{2}, \mathrm{Ru}\left(\mathrm{NH}_{3}\right)_{6} \mathrm{Cl}_{3}$, $\mathrm{Ru}\left(\mathrm{NH}_{3}\right)_{6} \mathrm{Cl}_{2}, \mathrm{Ru}(\mathrm{Iv}), \mathrm{Ru}(\mathrm{III})$ and $\mathrm{Ru}(\mathrm{II})$, respectively, reference compounds were obtained from Aldrich and used to determine the shift in the XANES energy due to change in oxidation state. Phase shifts, backscattering amplitudes were obtained from reference compounds: $\mathrm{RuO}_{2}(4 \mathrm{Ru}-\mathrm{O}$ at $1.99 \AA$ and $2 \mathrm{Ru}-\mathrm{O}$ at $1.94 \AA$, or an average of $6 \mathrm{Ru}-\mathrm{O}$ at $1.97 \AA)$ and $\mathrm{Ru}$ foil $(12 \mathrm{Ru}-\mathrm{Ru}$ at $2.68 \AA$ ). The XANES edge energy was determined from the inflection point of the leading edge, i.e., the maximum in the first derivative. Standard procedures using WINXAS3.1 software were used to extract the EXAFS data. The coordination parameters were obtained by a least square fit in $k$ - and $r$-space of the isolated multiple-shell, $k^{2}$-weighted Fourier transform data. The samples were also analyzed by X-ray photoelectron spectroscopy (XPS) using a VG Escalab MKII spectrophotometer, which operated with a non monochromatized $\mathrm{Mg} \mathrm{K}$ source $(1253.6 \mathrm{eV})$.

\subsection{Synthesis of $\mathrm{Ru}-\mathrm{C}_{60}$ nanostructures}

In a typical experiment ${ }^{51}$ the $[\mathrm{Ru}(\mathrm{COD})(\mathrm{COT})](\mathrm{COD}=1,5$ cyclooctadiene, COT $=1,3,5$-cyclooctatriene) complex was introduced in a Fisher-Porter bottle, and a solution of fullerene $\mathrm{C}_{60}$ in the desired solvent was then introduced in the reactor. The resulting purple solution was stirred for $30 \mathrm{~min}$ at room temperature, after which the bottle was pressurized with 3 bar of $\mathrm{H}_{2}$. The solution, which turned black after few minutes of reaction, was kept under stirring overnight at room temperature. After this period of time, excess of $\mathrm{H}_{2}$ was eliminated and the volume of solvent was reduced under vacuum. Pentane was then added to the colloidal suspension to precipitate the $\mathrm{Ru}-\mathrm{C}_{60}$ nanostructures. After filtration under argon with a cannula, the black solid powder was washed twice with pentane and filtrated again before drying under vacuum. For each ratio studied, the quantities of reactants are detailed hereafter:

$\mathrm{Ru}-\mathrm{C}_{60}$ 1/1: $30.0 \mathrm{mg}(0.10 \mathrm{mmol})$ of [Ru(COD)(COT)]; $68.5 \mathrm{mg}$ $(0.10 \mathrm{mmol})$ of fullerene $\mathrm{C}_{60}$ and $300 \mathrm{~mL}$ of $\mathrm{CH}_{2} \mathrm{Cl}_{2}$. Yield: 68.1 mg. Ru: $10.6 \%$.

$\mathrm{Ru}-\mathrm{C}_{60}$ 2/1: $80 \mathrm{mg}(0.25 \mathrm{mmol})$ of [Ru(COD)(COT)]; $91.3 \mathrm{mg}$ $(0.126 \mathrm{mmol})$ of fullerene $\mathrm{C}_{60}$ and $400 \mathrm{~mL}$ of $\mathrm{CH}_{2} \mathrm{Cl}_{2}$. Yield: 100 mg. Ru: $16.7 \%$.

$\mathrm{Ru}-\mathrm{C}_{60}$ 5/1: $200 \mathrm{mg}(0.63 \mathrm{mmol})$ of [Ru(COD)(COT)]; $91.3 \mathrm{mg}$ $(0.126 \mathrm{mmol})$ of fullerene $\mathrm{C}_{60}$ and $400 \mathrm{~mL}$ of $\mathrm{CH}_{2} \mathrm{Cl}_{2}$. Yield:129 mg. $\mathrm{Ru}: 35.6 \%$.

$\mathrm{Ru}-\mathrm{C}_{60}$ 10/1: $400 \mathrm{mg}(1.27 \mathrm{mmol})$ of [Ru(COD)(COT)]; 91.3 $\mathrm{mg}(0.126 \mathrm{mmol})$ of fullerene $\mathrm{C}_{60}$ and $400 \mathrm{~mL}$ of $\mathrm{CH}_{2} \mathrm{Cl}_{2}$. Yield: $188 \mathrm{mg}$. Ru: $48.7 \%$.

$\mathrm{Ru}-\mathrm{C}_{60}$ 20/1: $100 \mathrm{mg}(0.32 \mathrm{mmol})$ of $[\mathrm{Ru}(\mathrm{COD})(\mathrm{COT})] ; 11.4$ $\mathrm{mg}(0.016 \mathrm{mmol})$ of fullerene $\mathrm{C}_{60}$ and $50 \mathrm{~mL}$ of $\mathrm{CH}_{2} \mathrm{Cl}_{2}$. Yield: $36.9 \mathrm{mg}$. Ru: $50.4 \%$.

$\mathrm{Ru}-\mathrm{C}_{60}$ 30/1: $150 \mathrm{mg}(0.48 \mathrm{mmol})$ of [Ru(COD)(COT)]; 11.4 $\mathrm{mg}(0.016 \mathrm{mmol})$ of fullerene $\mathrm{C}_{60}$ and $50 \mathrm{~mL}$ of $\mathrm{CH}_{2} \mathrm{Cl}_{2}$. Yield: 48 mg. Ru: $54.7 \%$.

$\mathrm{Ru}-\mathrm{C}_{60}$ 50/1: $250 \mathrm{mg}(0.79 \mathrm{mmol})$ of $[\mathrm{Ru}(\mathrm{COD})(\mathrm{COT})] ; 11.4$ $\mathrm{mg}(0.016 \mathrm{mmol})$ of fullerene $\mathrm{C}_{60}$ and $50 \mathrm{~mL}$ of $\mathrm{CH}_{2} \mathrm{Cl}_{2}$. Yield: 80 mg. Ru: $61.9 \%$.

Growth mechanism. The reaction was performed at $-20{ }^{\circ} \mathrm{C}$ following the standard procedure: $20 \mathrm{mg}(0.064 \mathrm{mmol})$ of $[\mathrm{Ru}(\mathrm{COD})(\mathrm{COT})] ; 23 \mathrm{mg}(0.032 \mathrm{mmol})$ of fullerene $\mathrm{C}_{60}$ and 50 $\mathrm{mL}$ of $\mathrm{CH}_{2} \mathrm{Cl}_{2}$. The reaction was followed by sampling the mixture over the time.

Surface reactivity with CO. The adsorption of carbon monoxide on the surface of the nanostructures was performed in the solid state as follows. A purified sample of nanoparticles was introduced in a Fischer-Porter bottle. The reactor was pressurized with 1.5 bar of CO for $72 \mathrm{~h}$. Then, the CO gas was evacuated under vacuum for $20 \mathrm{~min}$ and the ATR-IR spectra were recorded.

\section{Results and discussion}

\subsection{Synthesis and TEM characterization of the $\mathrm{Ru}-\mathrm{C}_{60}$ nanostructures}

$\mathrm{Ru}-\mathrm{C}_{60}$ nanoarchitectures were synthesized by decomposing $[\mathrm{Ru}(\mathrm{COD})(\mathrm{COT})]$ under $\mathrm{H}_{2}$ (3 bar) in the presence of $\mathrm{C}_{60}$ at room temperature. The $\mathrm{Ru} / \mathrm{C}_{60}$ ratio was fixed to $2 / 1$ and the effect of the solvent the first to be studied. Several solvents (toluene, chlorobenzene, 1,2-dichlorobenzene, dichloromethane, chloroform and decalin) were used under the same reaction conditions except for $\mathrm{CHCl}_{3}$ and $\mathrm{CH}_{2} \mathrm{Cl}_{2}$, for which higher dilutions were used because of the low solubility of $\mathrm{C}_{60}$ in these solvents. TEM analyses of the $\mathrm{Ru}-\mathrm{C}_{60}$ structures (Fig. 1) show a marked effect of the solvent on the size and shape on the synthesized materials. 
The syntheses carried out in decalin lead to structures with very irregular shapes, decorated with small Ru NPs $(1.23 \pm 0.22$ $\mathrm{nm})$. The TEM analyses of the product of the reaction in toluene showed smaller shapeless structures with mean diameters of $c a$. $175 \mathrm{~nm}$. In this case, no NPs were detected from the TEM and HREM analyses (ESI.1†). Spherical particles were systematically obtained using chlorinated solvents or mixtures of toluene and $\mathrm{CH}_{2} \mathrm{Cl}_{2}$. TEM micrographs of the $\mathrm{Ru}-\mathrm{C}_{60}$ structures synthesized in chlorobenzene, 1,2-dichlorobenzene, $\mathrm{CHCl}_{3}$, and $\mathrm{CH}_{2} \mathrm{Cl}_{2}$ reveal spherical particles with mean diameters of $285 \pm 3 \mathrm{~nm}$, $200 \pm 3 \mathrm{~nm}, 229 \pm 1.5 \mathrm{~nm}$, and $40 \pm 0.7 \mathrm{~nm}$, respectively. Ru$\mathrm{C}_{60}$ particles synthesized in $\mathrm{CH}_{2} \mathrm{Cl}_{2}$ displayed a significantly smaller mean diameter and narrower size distribution; furthermore they were decorated with small Ru NPs $(1.15 \pm 0.02$ $\mathrm{nm})$. STEM-EDX mappings of the structures synthesized in toluene, 1,2-dichlorobenzene and dichloromethane confirm that they are composed of Ru and $\mathrm{C}$ even if Ru NPs are not observed (Fig. 2 and ESI.1†).

It is known that polymeric spheres of uniform size can be produced using mechanical methods..$^{52}$ In a first step, the polymers form long threads, which break into smaller droplets of uniform size due to Rayleigh instability. The size of the spheres is determined by the applied stress, and weakly depends on the viscosity ratio between the dispersed and the continuous phases. ${ }^{53,54}$ The polymer concentration has also an impact on the structure formed. ${ }^{55}$ If we assume that the $\mathrm{Ru}-\mathrm{C}_{60}$ spheres are polymeric and present similar properties (i.e.
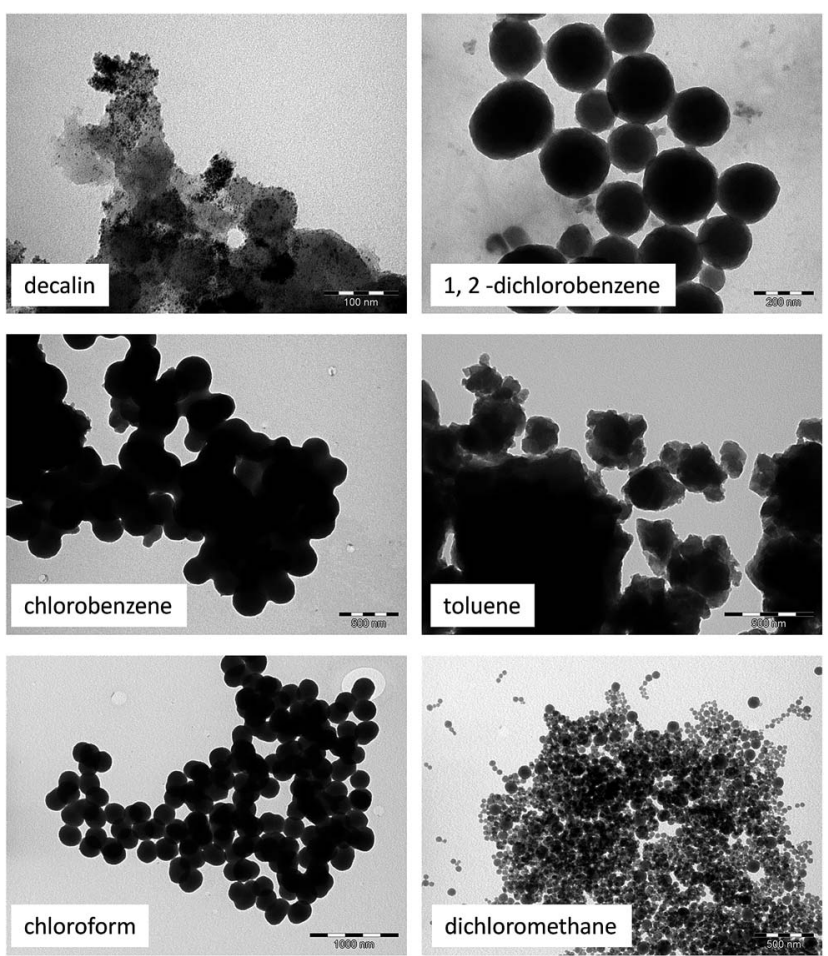

Fig. 1 TEM micrographs of Ru- $\mathrm{C}_{60}$ structures with $\mathrm{Ru} / \mathrm{C}_{60}=2 / 1$ synthesized in different solvents: decalin (scale bar $100 \mathrm{~nm}$ ), 1,2dichorobenzene (scale bar 200 nm), chlorobenzene (scale bar 500 $\mathrm{nm}$ ), toluene (scale bar $500 \mathrm{~nm}$ ), chloroform (scale bar $1000 \mathrm{~nm}$ ) and dichloromethane (scale bar $500 \mathrm{~nm}$ ).
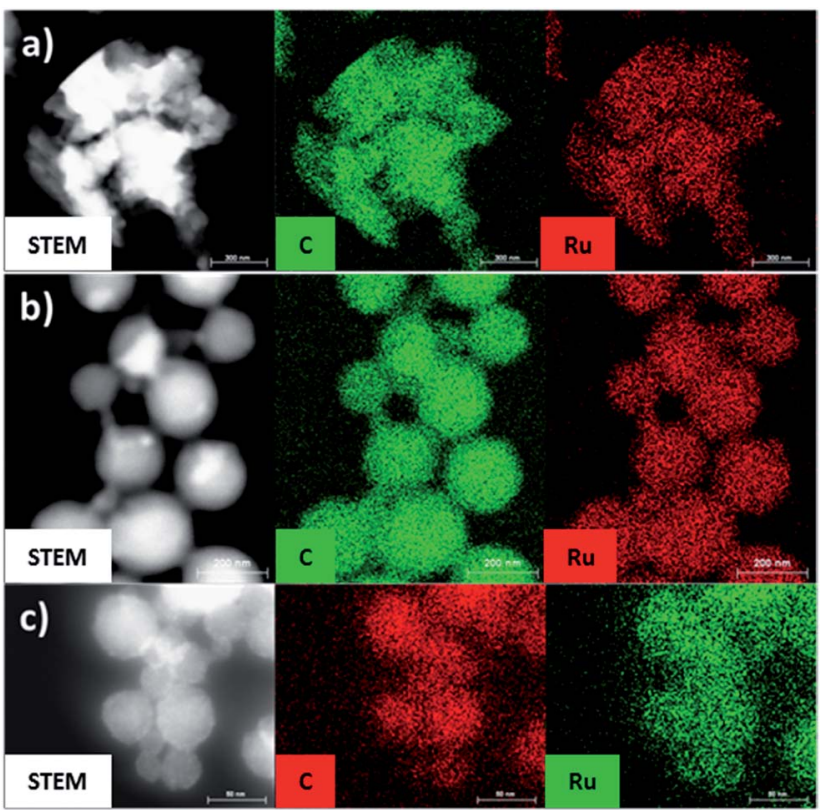

Fig. 2 STEM-EDX mappings of Ru- $\mathrm{C}_{60}(2 / 1)$ structures synthesized in: (a) toluene (scale bar $300 \mathrm{~nm}$ ); (b) 1,2-dichlorobenzene (scale bar 200 $\mathrm{nm}$ ); and dichloromethane (scale bar $50 \mathrm{~nm}$ ).

viscosity) in all the synthesis carried out, we can correlate the self-assembly of the polymer in spheres with the solvent viscosity but also permittivity (see ESI.2†). In decalin, which has the higher viscosity and the lower permittivity (see Table 1), no shape control is achieved, while in $\mathrm{CH}_{2} \mathrm{Cl}_{2}$ (lower viscosity and high permittivity), small spherical particles are produced.

The other solvents, showing intermediate viscosity, allow obtaining spheres as well, however, with larger mean diameters. The only exception is the material synthesized in toluene, which has, as decalin, a low permittivity. In order to unravel the growth mechanism of the spherical particles we monitored the reaction by $e x$ situ TEM analyses. The synthesis was realized in $\mathrm{CH}_{2} \mathrm{Cl}_{2}$ using a $\mathrm{Ru} / \mathrm{C}_{60}$ ratio of $2 / 1$ at low temperature $\left(-20{ }^{\circ} \mathrm{C}\right)$ because of the fast formation of the spheres at r.t. TEM micrographs of samples taken at different times are displayed in Fig. 3. As observed for the synthesis of polymeric spheres,${ }^{54}$ in a first step the big droplets deform into long threads: at $5 \mathrm{~min}$ of reaction, mainly elongated objects (with sizes ranging from 300 to $1000 \mathrm{~nm}$ ) are observed together with some spherical particles with diameters $c a .130 \mathrm{~nm}$. At $10 \mathrm{~min}$, the size of these objects ranged between 20 and $400 \mathrm{~nm}$.

After 40 min of reaction, big spheres are observed (mean diameter of $c a .290 \mathrm{~nm}$ ), which are clearly formed from the elongated objects. In the synthesis of polymeric particles a second step is observed, where the resulting droplets can again break up into daughter droplets. This second mechanism is much slower. We stirred the reaction overnight and a last sample was observed by TEM after $12 \mathrm{~h}$. This sample shows spherical particles of $37.0 \pm 0.3 \mathrm{~nm}$ mean diameter and big spherical particles of about $330 \mathrm{~nm}$. These results indicate that a second step towards the formation of smaller spheres is indeed active. TEM images clearly show that the 
Table 1 Solvent properties as related to the TEM analyses obtained for the Ru- $\mathrm{C}_{60}$ structures

\begin{tabular}{lllll}
\hline Solvent & $\begin{array}{l}\text { Viscosity } \\
(\mathrm{mPa} \mathrm{s})^{56}\end{array}$ & $\begin{array}{l}\mathrm{C}_{60} \text { solubility } \\
\left(\left[\mathrm{C}_{60}\right], \mathrm{mg} \mathrm{mL}^{-1}\right)^{57}\end{array}$ & $\begin{array}{l}\text { Relative } \\
\text { permittivity }\left(\varepsilon_{\mathrm{r}}\right)^{56}\end{array}$ & $\begin{array}{l}\text { TEM } \\
\text { analyses }\end{array}$ \\
\hline cis-Decalin & 3.042 & 4.6 & 2.22 & No shape control - structures decorated with Ru NP of $1.23 \pm 0.22 \mathrm{~nm}$ \\
trans-Decalin & 1.948 & & 2.18 & Spheres of $200 \pm 3 \mathrm{~nm}$ \\
1,2-Dichlorobenzene & 1.324 & 27 & 10.12 & Spheres of $285 \pm 3 \mathrm{~nm}$ \\
Chlorobenzene & 0.753 & 7 & 5.70 & No shape control of the structures of $c a .175 \mathrm{~nm}$ \\
Toluene & 0.560 & 2.8 & 2.38 & Spheres of $229 \pm 1.5 \mathrm{~nm}$ \\
Chloroform & 0.537 & 0.16 & 4.81 & Spheres of $39.6 \pm 0.7 \mathrm{~nm}$ decorated with Ru NP $1.15 \pm 0.02 \mathrm{~nm}$ \\
Dichloromethane & 0.413 & 0.26 & 8.93 &
\end{tabular}

small spheres $(\approx 40 \mathrm{~nm})$ are formed from the large $300 \mathrm{~nm}$ spheres.

The STEM-EDX maps of the $\mathrm{Ru}-\mathrm{C}_{60}$ structures synthesized at $-20{ }^{\circ} \mathrm{C}$ in $\mathrm{CH}_{2} \mathrm{Cl}_{2}$ (see ESI. $3 \dagger$ ) confirm that the structures observed in the early stages of the reaction are constituted by $\mathrm{Ru}$ and $\mathrm{C}$, as well as the spheres observed at $40 \mathrm{~min}$ of reaction. Nagashima et al. studied the synthesis of $\mathrm{Pd}_{n} \mathrm{C}_{60}$ polymer from $\left[\mathrm{Pd}_{2}(\mathrm{dba})_{3}\left(\mathrm{CHCl}_{3}\right)\right](\mathrm{dba}=$ dibenzylideneacetone $)$ in toluene

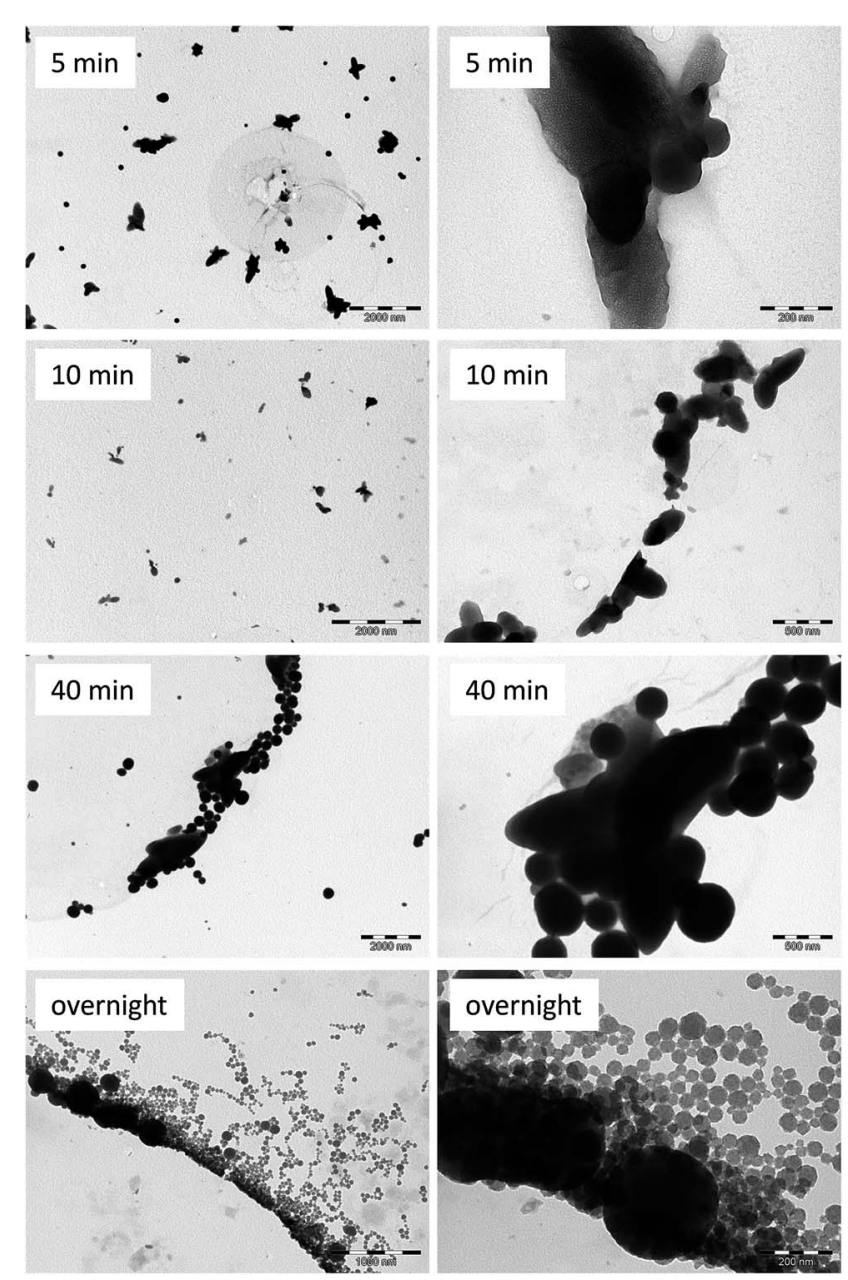

Fig. 3 TEM micrographs of $\mathrm{Ru}-\mathrm{C}_{60}$ structures synthesized in $\mathrm{CH}_{2} \mathrm{Cl}_{2}$ using a Ru/ $\mathrm{C}_{60}$ ratio of $2 / 1$ at $-20{ }^{\circ} \mathrm{C}$ (scale bar: $5 \mathrm{~min}, 2000$ and 200 $\mathrm{nm} ; 10 \mathrm{~min}, 2000$ and $500 \mathrm{~nm} ; 40 \mathrm{~min}, 2000$ and $500 \mathrm{~nm}$; and overnight, 1000 and $200 \mathrm{~nm}$ ). using several $\mathrm{Pd} / \mathrm{C}_{60}$ ratios. ${ }^{13}$ From microprobe analyses, they proposed a mechanism for the formation of $\mathrm{C}_{60} \mathrm{Pd}_{n}$, in which a one dimensional polymer $\mathrm{C}_{60} \mathrm{Pd}_{1}$ is formed at the first stage. Then, insertion of additional $\mathrm{Pd}$ atoms between the polymer chains make bridges to form $\mathrm{C}_{60} \mathrm{Pd}_{n}(n>1)$. For $\mathrm{C}_{60} \mathrm{Pd}_{n}(n>3)$, an excess of Pd atoms would be deposited on the surface of $\mathrm{C}_{60} \mathrm{Pd}_{3}$. In a study on $\mathrm{C}_{60}-\mathrm{Pd}$ film electrodeposition from palladium acetate, Gradzka et al. have shown that in the presence of a large excess of palladium precursor, Pd NPs can be deposited on the polymer surface..$^{58}$ In order to better understand the $\mathrm{Ru}$ system, we decided to explore the effect of the $\mathrm{Ru} /$ $\mathrm{C}_{60}$ ratio on the produced $\mathrm{Ru}-\mathrm{C}_{60}$ structures. Using $\mathrm{CH}_{2} \mathrm{Cl}_{2}$ as solvent we fixed the concentration of $\mathrm{C}_{60}$ and we progressively increased the ruthenium content to obtain $\mathrm{Ru} / \mathrm{C}_{60}$ ratios of 1,2 , $5,10,20,30$ and 50. The TEM images of the synthesized materials are shown in Fig. 4. The TEM and HREM analyses show that the $\mathrm{Ru}-\mathrm{C}_{60} 1 / 1$ sample does not contain $\mathrm{Ru}$ NPs. Increasing the Ru content, Ru NPs are observed. Ru NPs display in all cases a small mean diameter, even at high $\mathrm{Ru} / \mathrm{C}_{60}$ ratios, ranging from 1.10 to $1.35 \mathrm{~nm}$ (see Table 2 and ESI.4†). Interestingly, the $\mathrm{Ru}-\mathrm{C}_{60}$ spheres do not change significantly in size for $\mathrm{Ru} / \mathrm{C}_{60}$ ratios from $1 / 1$ to $10 / 1$ ( $\approx 40 \mathrm{~nm}$, ESI. $5 \dagger$ ). At a $20 / 1$ ratio, two size distributions are observed for the spheres: the major one centered at $39.8 \pm 1.1 \mathrm{~nm}$ together with some bigger spheres with mean diameter of $78.8 \pm 0.7 \mathrm{~nm}$ (see ESI.6 for size histograms $\dagger$ ). The $\mathrm{Ru}-\mathrm{C}_{60} 30 / 1$ sample also displayed spheres with a bimodal size distribution $(56.4 \pm 4.7 \mathrm{~nm}$ and $103.2 \pm 1.0$ $\mathrm{nm})$. At 50/1 ratio the mean diameter of the spheres is $63.3 \pm 0.8$ nm (Fig. 4 and Table 2). The 30/1, and more particularly, the 50/ 1 samples are also characterized by the presence of aggregated $\mathrm{Ru}$ NPs. These aggregated Ru NPs are very similar to the ones obtained by decomposition of the $[\mathrm{Ru}(\mathrm{COD})(\mathrm{COT})]$ precursor in the absence of $\mathrm{C}_{60}$ (ESI.7†).

The extremely small size of the $\mathrm{Ru}$ species present in the $\mathrm{Ru}-$ $\mathrm{C}_{60} 1 / 1$ sample is a drawback for a classical TEM analysis. To overcome this inconvenient, a scanning TEM in high-angle annular dark field (STEM) approach, based on the Z-contrast dependence, can be useful to identify the small metallic species supported in/on the lighter matrix. For the 1/1 ratio of $\mathrm{Ru}-\mathrm{C}_{60}$, the STEM-HAADF micrographs (Fig. 5a and b) show the presence of $\mathrm{Ru}$ atoms and/or clusters all over the surface of the spheres. The Ru clusters size does not exceed $0.6 \mathrm{~nm}$. In the case of a representative sphere for the 30/1 ratio (Fig. 5c and d) the HAADF micrographs show the presence of small Ru NPs with 

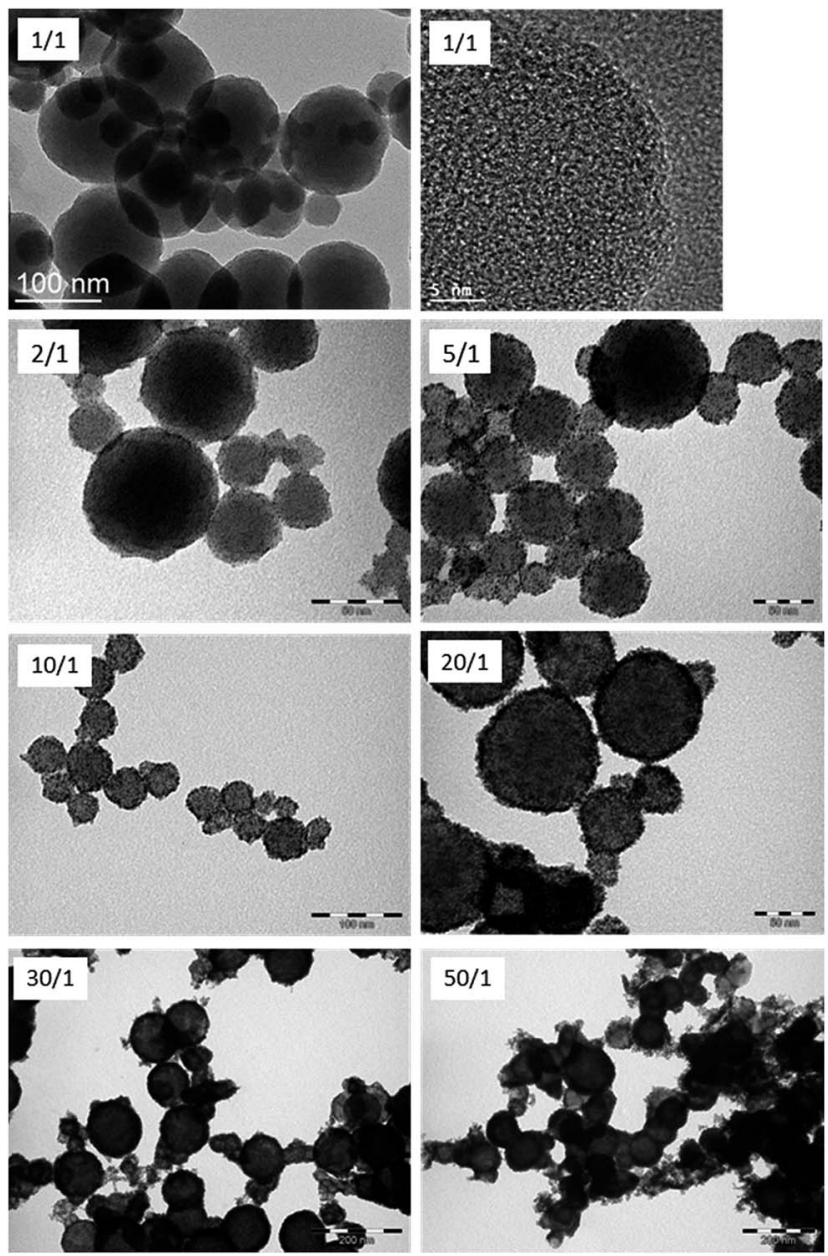

Fig. 4 TEM images of $\mathrm{Ru}-\mathrm{C}_{60}$ structures synthesized in $\mathrm{CH}_{2} \mathrm{Cl}_{2}$ using a Ru/ $\mathrm{C}_{60}$ ratio of $1 / 1$ (scale bar $100 \mathrm{~nm}$ and $5 \mathrm{~nm}$ ), 2/1 (scale bar $50 \mathrm{~nm}$ ), 5/1 (scale bar $50 \mathrm{~nm}$ ), 10/1 (scale bar $100 \mathrm{~nm}$ ), 20/1 (scale bar $50 \mathrm{~nm}$ ), 30/1 (scale bar $200 \mathrm{~nm}$ ) and 50/1 (scale bar $200 \mathrm{~nm}$ ).

a higher concentration of Ru on the surface of the sphere. The distribution of the Ru signal, acquired in STEM-EDX along a line scan, confirms the presence of Ru NPs on the outer sphere surface within the $30 / 1$ sample (ESI.8†), whereas a more

Table 2 Mean size diameters of Ru NPs and spheres of Ru- $\mathrm{C}_{60}$ according to the $\mathrm{Ru} / \mathrm{C}_{60}$ ratio

\begin{tabular}{llll}
\hline & & $\begin{array}{l}\text { Nanoparticles }_{\text {mean size }^{a}(\mathrm{~nm})} \\
\mathrm{Ru} / \mathrm{C}_{60}\end{array}$ & $\begin{array}{l}\text { Ru }(\%) \\
\operatorname{size}^{a}(\mathrm{~nm})\end{array}$ \\
\hline $1 / 1$ & 10.6 & Not observed & $39.1 \pm 0.5 \mathrm{~nm}$ \\
$2 / 1$ & 16.7 & $1.16 \pm 0.02 \mathrm{~nm}$ & $31.6 \pm 0.6 \mathrm{~nm}$ \\
$5 / 1$ & 35.6 & $1.31 \pm 0.03 \mathrm{~nm}$ & $42.6 \pm 1.0 \mathrm{~nm}$ \\
$10 / 1$ & 48.7 & $1.26 \pm 0.03 \mathrm{~nm}$ & $32.4 \pm 0.3 \mathrm{~nm}$ \\
$20 / 1$ & 50.4 & $1.10 \pm 0.01 \mathrm{~nm}$ & $39.8 \pm 1.1 \mathrm{~nm} \mid 85.2 \pm 2.9 \mathrm{~nm}$ \\
$30 / 1$ & 54.7 & $1.34 \pm 0.01 \mathrm{~nm}$ & $56.4 \pm 4.7 \mathrm{~nm}$ \\
& & & $\mid 103.2 \pm 1.0 \mathrm{~nm}$ \\
$50 / 1$ & 61.9 & $1.35 \pm 0.02 \mathrm{~nm}$ & $63.3 \pm 0.8 \mathrm{~nm}$
\end{tabular}

${ }^{a}$ Manual measurement from enlarged micrographs of at least 200 objects.
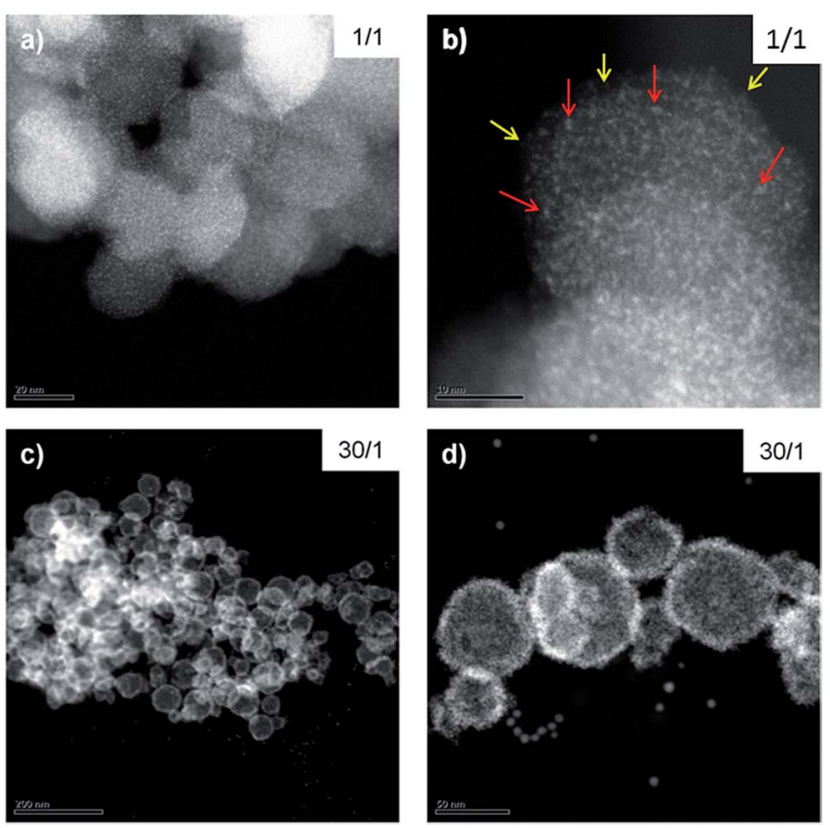

Fig. 5 (a) STEM-HAADF micrographs of Ru/ $\mathrm{C}_{60} 1 / 1$ (scale bar $20 \mathrm{~nm}$ ), (b) (scale bar $10 \mathrm{~nm}$ ), (c) STEM-HAADF micrographs of Ru/C 60 30/1 (scale bar $200 \mathrm{~nm}$ ), and (d) (scale bar $50 \mathrm{~nm}$ ) nanostructures. In (b), the yellow and red arrows point to the Ru few atom clusters and larger clusters, respectively.

uniform distribution of $\mathrm{Ru}$ is observed for the 1/1 sample (ESI.8 $\dagger$ ). The above TEM or STEM analyses on the $2 \mathrm{D}$ projections of the objects do not provide clear information on the possible presence of Ru species (clusters or small NPs) in the interior of the spheres. Electron tomography analysis allowed the investigation within the volume of theses spheres.

Fig. 6 shows the results obtained for the $30 / 1 \mathrm{Ru}-\mathrm{C}_{60}$ ratio. From the slices views of 3D reconstructed volumes (Fig. $6 \mathrm{~b}$ and c), the presence of small Ru NPs is obvious on the surface of the sphere, creating a Ru NP shell with a thickness around $7 \mathrm{~nm}$, which correspond to a multilayered NP structure. This is in agreement with the Ru signal distribution observed in Fig. 5c and $d$, as the heavier elements appear most contrasted in STEMHAADF, and also with the distribution of the $\mathrm{Ru}$ signal, acquired in STEM-EDX (ESI.8†). It is thus clear that no crystallized Ru NPs are present inside the spheres, but this analysis does not exclude the presence of atomic $\mathrm{Ru}$ inside the polymeric matrix. The analysis was also performed for the $\mathrm{Ru}-\mathrm{C}_{60}$ sample with a $1 / 1$ ratio, but the very small size of the clusters prevents their localization (see ESI.9†), the size of the clusters being below the resolution limit for the electron tomography analysis. The resolution attained in electron tomography is in the nanometer range, thus it is practically impossible to evidence the presence of any metal atoms and/or few-atom clusters within the spheres. It is therefore reasonable to propose that, in $\mathrm{CH}_{2} \mathrm{Cl}_{2}$, the decomposition of the $[\mathrm{Ru}(\mathrm{COD})(\mathrm{COT})]$ precursor leads to the formation of polymeric spheres containing $\mathrm{Ru}$ atoms or small clusters and fullerenes at low $\mathrm{Ru}-\mathrm{C}_{60}$ ratio $(\leq 1)$, and that further increase of the $\mathrm{Ru}-\mathrm{C}_{60}$ ratio lead to $\mathrm{Ru}$ atoms, 

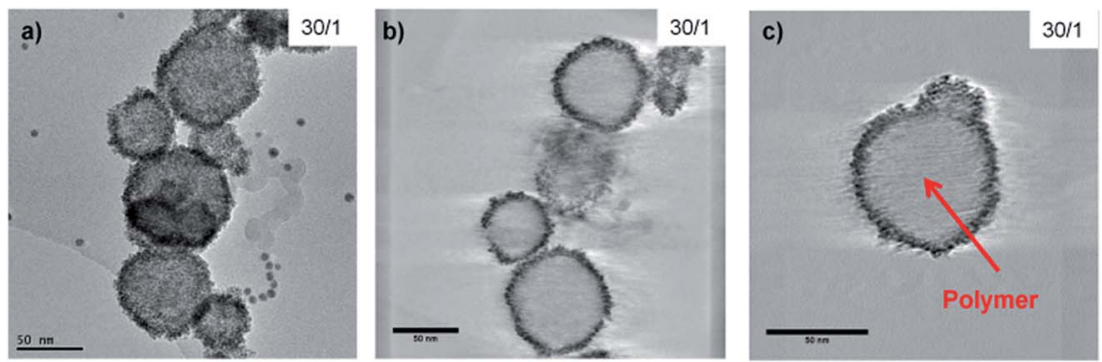

Fig. 6 3D analysis of Ru/ $\mathrm{C}_{60} 30 / 1$ by electron tomography: (a) bright field TEM images at $0^{\circ}$ tilt from the tilt series; (b) and (c) representative cross-sectional slices along one direction in the plane of 3D reconstructed volume showing the location of shell of Ru $2 \mathrm{~nm}$ size NPs on the surface of the sphere. The thickness of the shell is $7 \mathrm{~nm}$ (scale bar $50 \mathrm{~nm}$ ).

clusters or NPs deposition on the surface of these polymeric spheres.

The addition of extra $\mathrm{Ru}$ atoms in the polymeric spheres might be prevent by diffusional limitations. We checked independently that the decomposition of an excess of $[\mathrm{Ru}(\mathrm{COD})(-$ COT)] on the $\mathrm{Ru}-\mathrm{C}_{60} 1 / 1$ sample, to reach a $10 / 1$ ratio, leads to NPs deposition outside the $\mathrm{Ru}-\mathrm{C}_{60} 1 / 1$ spheres (ESI.10†).

Cold FEG confirmed de absence of clusters on the $\mathrm{Ru}-\mathrm{C}_{60}$ matrix of 1/1 sample (Fig. 7).

\subsection{DFT calculations on the $\mathrm{Ru}-\mathrm{C}_{60}$ nanoarchitectures}

There are five possible sites on $\mathrm{C}_{60}$ surface where $\mathrm{Ru}$ atoms may be adsorbed: (i) an atop site $\left(\eta^{1}\right)$ on which the $\mathrm{Ru}$ atom is coordinated to a single carbon atom, (ii) a bridge site between two hexagonal rings $\left(\eta^{2(6)}\right)$, (iii) a bridge site between pentagonal and hexagonal rings $\left(\eta^{2(5)}\right)$ on which a $\mathrm{Ru}$ atom sits on the $\mathrm{C}-\mathrm{C}$ bond and forms two $\mathrm{Ru}-\mathrm{C}$ bonds, (iv) a hollow site above the center of a pentagonal ring of $\mathrm{C}$ atoms $\left(\eta^{5}\right)$, and (v) a hollow site above the center of a hexagonal ring of $\mathrm{C}$ atoms $\left(\eta^{6}\right) .{ }^{59}$ For a single $\mathrm{Ru}$ atom interacting with one $\mathrm{C}_{60}$, the most stable configuration is $\eta^{2(6)}$, with an adsorption energy of $-48 \mathrm{kcal}$ $\mathrm{mol}^{-1}$, followed by $\eta^{2(5)}, \eta^{6}, \eta^{5}$, with energies of $-39,-38$, and

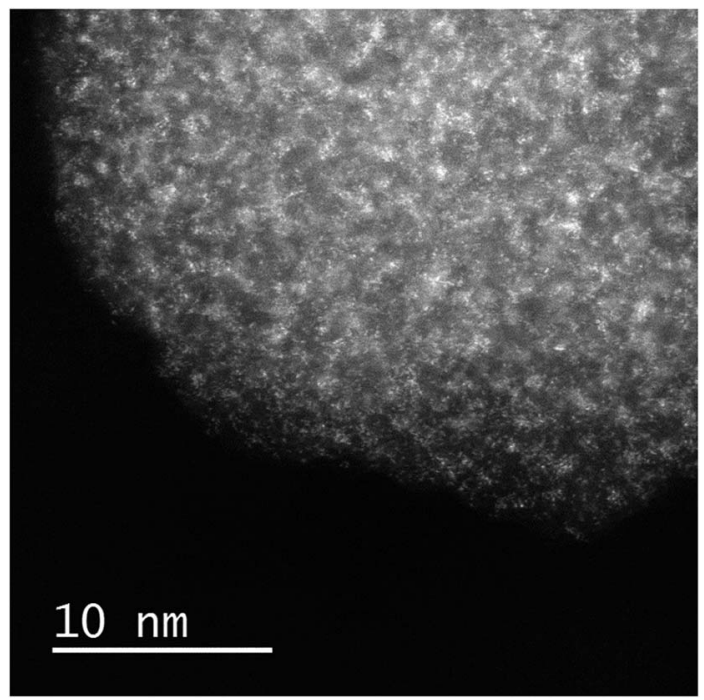

Fig. 7 STEM-HAADF micrographs of Ru/ $\mathrm{C}_{60} 1 / 1$.
$-35 \mathrm{kcal} \mathrm{mol}^{-1}$ respectively, when the atop site is instable. The better stability of the $\eta^{2(6)}$ site is not surprising, as the double bond shared by two hexagons corresponds to a maximum of the electronic density of the fullerene. Experimentally, this coordination mode has been observed for Pt complexes and suspected for $\mathrm{Ru}$ ones. ${ }^{60}$ These adsorption energies are significantly larger than the ones obtained for $\mathrm{Ni}, \mathrm{Au}$ or $\mathrm{Ta}$ atoms for instance, with typical values smaller than $-25 \mathrm{kcal} \mathrm{mol}^{-1,31,33,34}$ but remain in very good agreement with values obtained for Rh, Ir, Pd and Pt atoms. ${ }^{36} \mathrm{Pt}$ atoms bind more strongly than $\mathrm{Ru}$ ones on $\mathrm{C}_{60}$ since, using the same computational settings; the adsorption energy of a Pt atom is already $-66 \mathrm{kcal} \mathrm{mol}^{-1}$. This value is also in good agreement with previously reported values. ${ }^{36,61,62}$ For the $\eta^{2(6)}$ and $\eta^{2(5)}$ sites, the smallest $\mathrm{Ru}-\mathrm{C}$ bond lengths are $2.06 \AA$. Then, the $\mathrm{Ru}-\mathrm{C}$ bond length increases with the increase of adsorption energy for the different sites. For the $\eta^{6}$ site, two $\mathrm{Ru}-\mathrm{C}$ bondlengths are 2.25 , two others $\mathrm{Ru}-\mathrm{C}$ distances are 2.34 when the last ones are $2.42 \AA$. It means that a single Ru prefers to lie in a displaced hollow site than a highly symmetric site. Finally, the $\mathrm{Ru}-\mathrm{C}$ distances in the less stable site, i.e. in the $\eta^{5}$ position, are $2.21 \AA$. Interestingly the most stable $\mathrm{Ru}-\mathrm{C}_{60}$ complex is magnetic with a moment of $2 \mu_{\mathrm{B}}$.

If now, we take into account the real source of $\mathrm{Ru}$ in the calculation, the $[\mathrm{Ru}(\mathrm{COD})(\mathrm{COT})]$ precursor, we have to consider that it may coordinate even when it is partially decomposed. The $[\mathrm{Ru}(\mathrm{COD})]$ species adsorbs, in a $\eta^{2(6)}$ site, with two short $\mathrm{Ru}-\mathrm{C}$ bond-lengths of $2.11 \AA$ and adsorption energy of $-58 \mathrm{kcal} \mathrm{mol}^{-1}$. The $\eta^{1}$ site has almost the same energy but with a smaller $\mathrm{Ru}-\mathrm{C}$ distance, i.e. $2.04 \AA$ A. On the contrary, the [Ru(COT)] species has a preference for the $\eta^{1}$ site, with an adsorption energy of -38 $\mathrm{kcal} \mathrm{mol}^{-1}$, the $\eta^{2(6)}$ site is $4 \mathrm{kcal} \mathrm{mol}^{-1}$ higher. However when using the following energy balances: $[\mathrm{Ru}(\mathrm{COD})(\mathrm{COT})]+\mathrm{C}_{60} \rightarrow$ $[\mathrm{Ru}(\mathrm{COT})] @ \mathrm{C}_{60}+\mathrm{COD}$ or $[\mathrm{Ru}(\mathrm{COD})(\mathrm{COT})]+\mathrm{C}_{60} \rightarrow[\mathrm{Ru}(\mathrm{COD})]$ (a) $\mathrm{C}_{60}+\mathrm{COT}$, meaning that we take into account the precursor dissociation energy, the energy differences become largely positive: +21 and $+28 \mathrm{kcal} \mathrm{mol}^{-1}$, respectively. As a result the precursor has to be completely decomposed by the action of $\mathrm{H}_{2}$ in order to allow for the creation of $\mathrm{Ru}-\mathrm{C}_{60}$ bond, and no partially decomposed $\mathrm{Ru}$ complexes can be stabilized on $\mathrm{C}_{60}$ surfaces.

In interaction with 2 fullerenes, a single Ru atom will preferably coordinate in a $\eta^{2}-\eta^{2}$ position, bridging two $\eta^{2(6)}$ positions, with $4 \mathrm{Ru}-\mathrm{C}$ bond-lengths of $2.07 \AA$, as shown in Fig. 8a. 
This complex adopts then a dumbbell like structure, as for a $\mathrm{Ni}^{31,63}$ or $\mathrm{Pt}$ atoms. ${ }^{36,61,62}$ The corresponding stabilization energy of this nonmagnetic complex is large, $-44 \mathrm{kcal} \mathrm{mol}^{-1}$, when adding a $\mathrm{C}_{60}$ to an existing $\mathrm{Ru}-\mathrm{C}_{60}$ complex. However, this binding energy for a Ru complex is still lower than the value of $-65 \mathrm{kcal} \mathrm{mol}^{-1}$, obtained at a semi-empirical level, on a $\mathrm{C}_{60}-\mathrm{Pt}-$ $\mathrm{C}_{60}$ complex. ${ }^{62}$ It suggests again that a $\mathrm{Ru}$ atom has a little less affinity for $\mathrm{C}_{60}$ than a $\mathrm{Pt}$ one. Interestingly, another stable structure that exhibits a $\eta^{2(6)}-\eta^{6}$ coordination mode, as it can be seen from Fig. 8b, lies only $12 \mathrm{kcal} \mathrm{mol}^{-1}$ higher in energy. The corresponding $\mathrm{Ru}-\mathrm{C}$ distances are ranging from 2.07 to $2.85 \AA$ for this site that connects $8 \mathrm{C}$ to the $\mathrm{Ru}$ atom. This relatively small energy difference between the two coordination modes can be reduced by 5 extra $\mathrm{kcal} \mathrm{mol}^{-1}$ due to the presence of adsorbed hydrogen atoms on the $\mathrm{C}_{60}$, as proposed experimentally, $c f$. Section 2.3, in the vicinity of the Ru atom (ESI.11†). Indeed a significant change of the $\mathrm{Ru}$ coordination is observed upon $\mathrm{H}_{2}$ adsorption since the most stable structure possesses a $\eta^{2(6)}-\eta^{4}$ character. More details on the $\mathrm{H}_{2}$ adsorption thermodynamics are provided in ESI. $\dagger$ In the case of the dumbbell like structure (Fig. 8a) it seems obvious that a third $\mathrm{C}_{60}$ can be easily coordinated to the central $\mathrm{Ru}$ atom. This reaction is still thermodynamically favorable but the energy gain is only -11 $\mathrm{kcal} \mathrm{mol}^{-1}$, due to the coordination mode of the third fullerene that is $\eta^{1}$. This stable $\mathrm{Ru}\left(\mathrm{C}_{60}\right)_{3}$ configuration might be viewed as a potential linker between ideal linear polymeric chains, as described in the following. The two $\mathrm{C}_{60}-\mathrm{Ru}-\mathrm{C}_{60}$ complexes (Fig. 8a and b) can thus be viewed as elementary bricks for hypothetical $1 \mathrm{D}$ chains made of $-\mathrm{C}_{60}-\mathrm{Ru}-\mathrm{C}_{60}-$ with a $1 \mathrm{Ru} / 1 \mathrm{C}_{60}$ ratio. Fig. $8 \mathrm{~d}$ shows a first model made of a unit cell that contains only $1 \mathrm{Ru}$ and $1 \mathrm{C}_{60}$. The corresponding optimized lattice constant is around $10.4 \AA$. In this particular state, the a)

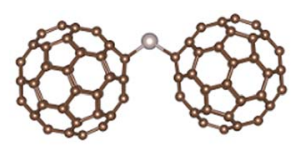

b)

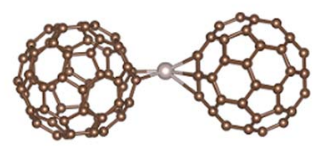

c)

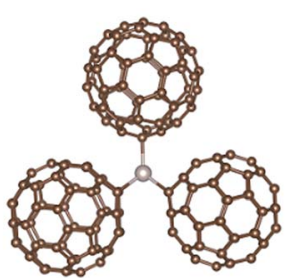

d)

e)

f)

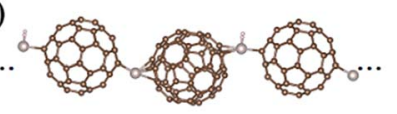

g)

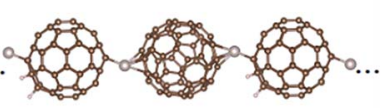

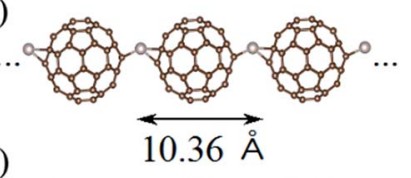

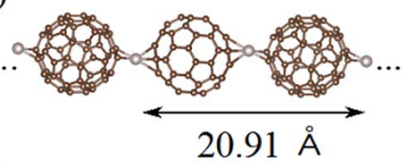

Fig. 8 (a) Side views of $\mathrm{C}_{60}-\mathrm{Ru}-\mathrm{C}_{60}$ complex in the dumbbell like structure, (b) in the $\eta^{2(6)}-\eta^{6}$ coordination mode, and (c) of the most stable $\mathrm{Ru}-\left(\mathrm{C}_{60}\right)_{3}$ complex. (d) Ideal $1 \mathrm{D}$ chains and their corresponding lattice parameters for $1 \mathrm{Ru} / 1 \mathrm{C}_{60}$ ratio for the $\eta^{2(6)}-\eta^{4}$ in state, and (e) for the $\eta^{2(6)}-\eta^{6}$ state. (f) Partially hydrogenated ideal polymeric chains with one Ru atom hydrogenated, and $(\mathrm{g})$ with one $\mathrm{C}_{60}$ hydrogenated. $\mathrm{Ru}$ atoms are in grey, carbon atoms in brown and $\mathrm{H}$ in white. four smallest $\mathrm{Ru}-\mathrm{C}$ distances are lying in 2.04 to $2.11 \AA$ range and two others are at 2.42 and $2.45 \AA$, when the next nearest $\mathrm{C}$ atoms are $2.66 \AA$ away. As a consequence the $\mathrm{Ru}$ atom has a $\eta^{2(6)}-\eta^{4}$ coordination mode in this case. To allow for more flexibility in the coordination mode, we have also used a model made of $2 \mathrm{Ru}$ atoms and $2 \mathrm{C}_{60}$ in the calculation cell. As a result of rotating slightly one of the $\mathrm{C}_{60}$ molecule on a vertical axe, a $\eta^{2(6)}-\eta^{6}$ coordination mode is stabilized, as shown in Fig. 8e.

In this structure a $\mathrm{Ru}$ atom does not have a perfect hollow position with 8 different $\mathrm{Ru}-\mathrm{C}$ bond-lengths: 2.04, 2.11, 2.14, $2.18,2.34,2.44,2.53$ and $2.57 \AA$. Almost the same values are yielded for the second metallic center (Fig. 9). This coordination mode is in good agreement with EXAFS results as shown below.

If we now try to complete the coordination sphere of one Ru atom by approaching a $\mathrm{H}_{2}$ molecule, it spontaneously dissociates and push the Ru to change its coordination to be $\eta^{2(6)}-\eta^{3}$ with two additional Ru-H distances are $1.59 \AA$, see Fig. $8 f$. When these two hydrides are transferred to one of the $C_{60}$, the $\eta^{2(6)}-\eta^{6}$ coordination modes are recovered but with a slight elongation of the largest $\mathrm{Ru}-\mathrm{C}$ distances, that are now between 2.60 and $2.70 \AA$ (Fig. 8g). In these cases, the $\mathrm{Ru}$ atoms provide large electronic density to the neighboring $\mathrm{C}_{60}$, with a charge transfer of around $0.6 e^{-}$. This value is not surprising since $\mathrm{C}_{60}$ is a wellknown electron acceptor and it is in reasonable agreement with Raman spectroscopy results, see below.

From the different microscopy techniques, it seems obvious that outside the spheres that contain the polymeric phase, $\mathrm{Ru}$ NPs are formed. To propose an answer at the molecular level of this statement, we have addressed two issues: are the thermodynamics in favor of Ru NPs formation? Could it be the solvent that protects metallic atoms and avoid $\mathrm{Ru}-\mathrm{Ru}$ formation bonds?

Starting from an ideal polymeric 1D chain, and thus adding a second metal atom is indeed energetically favorable; as well as adding 2 other ones, as it can be seen in Table 3. An interesting feature is that the lattice parameter values are increased to accommodate the creation of new $\mathrm{Ru}-\mathrm{C}$ bonds, and thus could be experimentally detected. Moreover the distance between the two $\mathrm{Ru}_{1}-\mathrm{Ru}_{2}$ in Fig. 10a is very unusual for metallic bond with a value of $2.28 \AA$. With $4 \mathrm{Ru}$ atoms, see Fig. $10 \mathrm{~b}$, the $R u_{4}-\mathrm{Ru}_{2}$ bond-length is $2.26 \AA$, the $R u_{1}-R_{2}$ is slightly elongated (+0.09 $\AA$ ) when the last one is $2.35 \AA$. From Table 3 , where energy gains per Ru atom are compiled in various binding situations, i.e. in single complex with different ratio $\mathrm{Ru} / \mathrm{C}_{60}$, in some ideal $1 \mathrm{D}$ polymeric chains or even in small cluster models and finally in the bulk, we can provide some interesting insights of the reaction media behavior. Indeed, when comparing the stabilization energies of a Ru atom involved in a 1D chain, and one in small

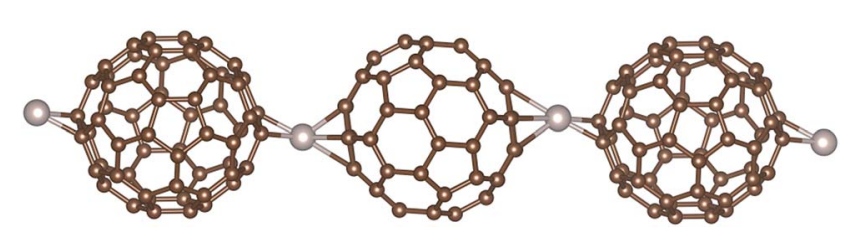

Fig. 9 Side view of an ideal $1 D$ chain for $1 R u / 1 C_{60}$ ratio in the $\eta^{2(6)}-\eta^{6}$ state. Ru atoms are in grey, carbon atoms in brown. 
Table 3 Energy stabilization per Ru atom in various systems: for single $\mathrm{C}_{60}-\mathrm{Ru}$ complexes, for different linear chains with different $\mathrm{Ru} / \mathrm{C}_{60}$ ratio, for two pure small metallic nanoparticles and in the bulk, with isolated $\mathrm{Ru}$ atom serving as the energy reference

\begin{tabular}{ll}
\hline Systems & Energy gain $\left(\mathrm{kcal} \mathrm{mol}^{-1}\right)$ \\
\hline $\mathrm{C}_{60}-\mathrm{Ru}$ & -48 \\
$\left(\mathrm{C}_{60}\right)_{2}-\mathrm{Ru}$ & -92 \\
$\left(\mathrm{C}_{60}\right)_{3}-\mathrm{Ru}$ & -103 \\
$\ldots-\mathrm{C}_{60}-\mathrm{Ru}-\mathrm{C}_{60}-\ldots$ & -86 \\
$\ldots-\mathrm{C}_{60}-\mathrm{Ru}_{2}-\mathrm{C}_{60}-\ldots$ & -94 \\
$\ldots-\mathrm{C}_{60}-\mathrm{Ru}_{3}-\mathrm{C}_{60}-\ldots$ & -106 \\
$\ldots-\mathrm{C}_{60}-\mathrm{Ru}_{4}-\mathrm{C}_{60}-\ldots$ & -76 \\
$\mathrm{Ru}_{13}$ & -96 \\
$\mathrm{Ru}_{55}$ & -123 \\
$\mathrm{Ru} \mathrm{bulk}$ & -153 \\
\end{tabular}

clusters or even worse in the bulk, it is clear that a $\mathrm{Ru}$ atom prefers to bind to other $\mathrm{Ru}$ atoms.

If one considers $\mathrm{Ru}_{13}$ cluster formation energy ( $-96 \mathrm{kcal}$ $\mathrm{mol}^{-1}$ ) the two processes are thermodynamically favorable. At this step, one can assume that the polymeric phase, with a ratio close to $1 \mathrm{Ru} / 1 \mathrm{C}_{60}$ without excluding small clusters of $\mathrm{Ru}_{n}(n \leq 3)$ linking fullerenes is the kinetic product of the reaction and then larger $\mathrm{Ru} \mathrm{NPs}$ are created, producing the thermodynamic products of the reaction. To support this idea we have also calculated the binding energy of $\mathrm{Ru}_{13}-\left(\mathrm{C}_{60}\right)_{x}$ complexes with $x$ up to 6 . The corresponding values are slightly lower than the other values given in Table 3: the energy gain per $\mathrm{C}_{60}$ is maximal for $x=1$ and $x=2$, with -87 and $-88 \mathrm{kcal} \mathrm{mol}^{-1}$ respectively, and decreases when $x$ increases: $-77,-74,-61 \mathrm{kcal} \mathrm{mol}^{-1}$. See ESI.12 $\uparrow$ for molecular models of the stable $\mathrm{Ru}_{13}-\mathrm{C}_{60}, \mathrm{Ru}_{13}{ }^{-}$ $\left(\mathrm{C}_{60}\right)_{2}$, and $\mathrm{Ru}_{13}-\left(\mathrm{C}_{60}\right)_{6}$ complexes. It means that when fullerenes are in excess, they have also the possibility to strongly bind metallic NPs.

However, in the present theoretical picture of the system, it is not clear why the polymeric phase is stabilized and has a net preference for the $1 \mathrm{Ru} / 1 \mathrm{C}_{60}$ ratio. To propose a reasonable explanation, at the atomic scale, we have further investigated the effects of two different solvent molecules, i.e. toluene and dichloromethane, on the stabilization of the polymeric phase. Since the solvent molecules interact only weakly with the metallic center, see ESI.13 $\uparrow$ for a more detailed discussion, the

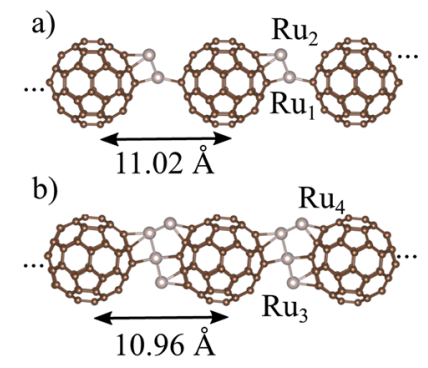

Fig. 10 (a) Side views and lattice parameters corresponding to a $2 \mathrm{Ru} /$ $\mathrm{C}_{60}$ and (b) $4 \mathrm{Ru} / \mathrm{C}_{60}$ ratio. $\mathrm{Ru}$ atoms are in grey, carbon atoms in brown. main reason is only a steric effect that avoid the agglomeration of $\mathrm{Ru}$ atoms.

\subsection{Infrared, NMR and Raman characterization}

The attenuated total reflectance infrared (ATR-IR) spectra were recorded for $\mathrm{Ru}-\mathrm{C}_{60}$ samples in the solid state (ESI.12 $\dagger$ ). Characteristic peaks of $\mathrm{C}_{60}$ are observed at 524, 576, 1182 and 1422 $\mathrm{cm}^{-1}$, together with other vibrations in the ranges 2800-3000 $\mathrm{cm}^{-1}$ (C-H stretching) and 400-1600 $\mathrm{cm}^{-1}$ (C-H bending, C-C stretching, $\mathrm{C}-\mathrm{H}$ out of plane). Some of the peaks have been attributed to $\mathrm{C}_{60} \mathrm{H}_{18}$ (ref. 64) and $\mathrm{C}_{60} \mathrm{H}_{36}$ (ref. 65) species, the rest of the peaks are probably due to the presence of a mixture of hydrofullerenes with different number of hydrogen atoms. ${ }^{66,67}$ The presence of fullerene in the samples was also confirmed by MAS ${ }^{13} \mathrm{C}\left\{{ }^{1} \mathrm{H}\right\}$ NMR, with a signal at $143.2 \mathrm{ppm}$ for $\mathrm{Ru}-\mathrm{C}_{60} 1 / 1,2 /$ 1, 5/1 and 10/1 samples (see ESI.13†). The ${ }^{13} \mathrm{C}\left\{{ }^{1} \mathrm{H}\right\}$ MAS NMR also show a low intensity broad signal at $40 \mathrm{ppm}$. The CP-MAS ${ }^{13} \mathrm{C}$ NMR ( $\mathrm{CP}={ }^{1} \mathrm{H}^{-13} \mathrm{C}$ cross polarization) allowed to clearly observe the broad signal at $40 \mathrm{ppm}$, which increased the intensity with increasing the Ru content. We attributed this broad signal to the presence of a mixture of hydrogenated fullerenes, ${ }^{64,68-72}$ as observed by ATR-IR. This was also confirmed by ${ }^{1} \mathrm{H}$ MAS NMR with the presence of a large peak at $4.5 \mathrm{ppm}$. However, the low intensity of these peaks indicates that fullerene hydrogenation is only a side reaction. If usually high temperatures and pressures are necessary for fullerene hydrogenation, ${ }^{73,74}$ the hydrogenation of $\mathrm{C}_{60}$ on $\mathrm{Rh} / \mathrm{Al}_{2} \mathrm{O}_{3}$ catalyst at ambient temperature and pressure has already been reported. ${ }^{75}$

a)
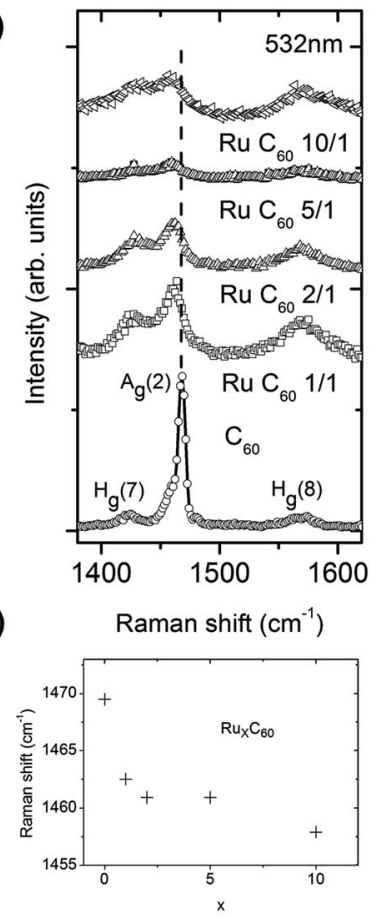

Fig. 11 (a) Raman spectra excited at $532 \mathrm{~nm}$ of $\mathrm{C}_{60}$ and $\mathrm{Ru}-\mathrm{C}_{60} 1 / 1,2$ / $1,5 / 1$ and $10 / 1$ samples in the spectral range of the tangential pitch mode $A_{g}(2)$; and (b) Raman spectral position of the $A_{g}(2)$ band as a function of molar concentration of $\mathrm{C}_{60}$. 
Since carbon monoxide is a sensitive probe for studying the surface composition of metal NPs, the CO adsorption on the $\mathrm{Ru}-\mathrm{C}_{60}$ nanostructures was investigated by ATR-IR. Carbon monoxide was reacted with solid samples of $\mathrm{Ru}-\mathrm{C}_{60}$ in a FisherPorter bottle under mild conditions (1.5 bar of CO, r.t., $24 \mathrm{~h}$ ). Then, ATR-IR spectra were recorded with a spectrometer available in a glove box (ESI.12b $\dagger$ ). After CO exposure $\mathrm{Ru}-\mathrm{C}_{60} 1 / 1,2 / 1$, 5/1 and 10/1 samples display three new peaks between 1900 and $2130 \mathrm{~cm}^{-1}$, which are typical of adsorbed terminal CO species. In the $\mathrm{Ru}-\mathrm{C}_{60} 1 / 1$ nanostructure, the peaks appear at 1998, 2053 and $2120 \mathrm{~cm}^{-1}$. The $\left[\mathrm{Ru}(\mathrm{CO})_{3}(\text { alkene })_{2}\right]$ complexes typically show three adsorption bands in the $\mathrm{CO}$ stretching region, in particular $\left[\mathrm{Ru}(\mathrm{CO})_{3}\left(\mathrm{C}_{2} \mathrm{H}_{4}\right)_{2}\right]$ complex display three bands at 2081, 2005 and $1995 \mathrm{~cm}^{-1} \cdot{ }^{76-78}$ Considering that $\mathrm{C}_{60}$ acts as an electron-deficient olefin, the bands should be shifted to highest stretching frequencies in a $\left[\mathrm{Ru}(\mathrm{CO})_{3}\left(\eta^{2}-\mathrm{C}_{60}\right)_{2}\right]$ species compared to $\left[\mathrm{Ru}(\mathrm{CO})_{3}\left(\mathrm{C}_{2} \mathrm{H}_{4}\right)_{2}\right]$, fitting with the spectrum obtained for the $\mathrm{Ru}-\mathrm{C}_{60} 1 / 1$ nanostructure, i.e. CO molecules are likely to coordinate to the $\mathrm{Ru}$ atoms in a polymeric structure to form species such as $\left[\mathrm{Ru}(\mathrm{CO})_{3}\left(\mu-\eta^{2}, \eta^{2}-\mathrm{C}_{60}\right)\right]_{\infty}$. However, species containing more or less CO ligands, as well as a mixture of species, cannot be discarded, as the signals are relatively broad. $\mathrm{Ru}-\mathrm{C}_{60} 2 / 1,5 / 1$ and 10/1 samples show the same pattern, although the signal at $1998 \mathrm{~cm}^{-1}$ becomes broader when increasing the Ru content. We assigned this broad signal, which increases in intensity with the number of Ru NPs present on the sample, to terminal CO adsorbed on the Ru NPs surface as it usually appears in the region of $1970-2000 \mathrm{~cm}^{-1} \cdot{ }^{79,80}$ For higher $\mathrm{Ru}-\mathrm{C}_{60}$ ratios, the ATR-IR signal intensity was too low for interpretation.

$\mathrm{C}_{60}$ is a well-known electron acceptor and Raman spectroscopy can give valuable information on charge transfer. Fig. 11a shows Raman spectra excited at $532 \mathrm{~nm}$ of $\mathrm{C}_{60}$ and $\mathrm{Ru}-\mathrm{C}_{60} 1 / 1$, $2 / 1,5 / 1$ and $10 / 1$ samples, in the spectral range of the tangential pitch mode $A_{g}(2)$. It has been shown that the energy of the $A_{g}(2)$ mode $\left(1468 \mathrm{~cm}^{-1}\right.$ for pure $\left.\mathrm{C}_{60}\right)$ is sensitive to charge transfer when evaporating $\mathrm{C}_{60}$ on metal surfaces, ${ }^{81}$ or for transition metal fullerides. ${ }^{19}$ While the charge transfer depends on the work function of the metal, other factors such as screened metal-adsorbate interactions and the effect of covalent bond
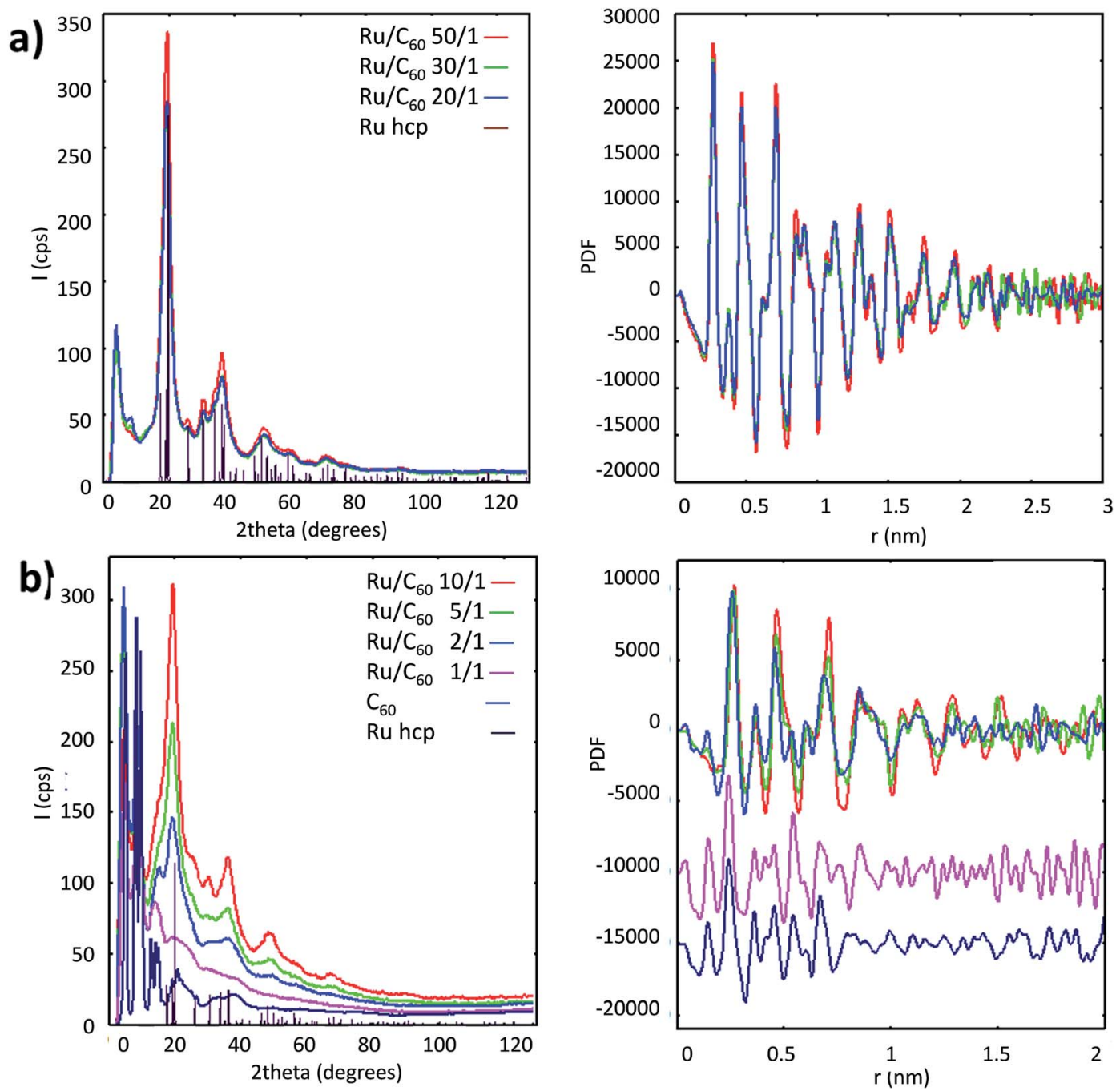

Fig. 12 (a) Left - diffractograms for high Ru/C 60 ratio together with Ru hcp reference data, right - related PDF. (b) Left - diffractograms for lower $\mathrm{Ru} / \mathrm{C}_{60}$ ratio with $\mathrm{Ru}$ hcp reference data, right - related PDF. 
formation may also influence the observed spectral shift, but are believed to be less important. It is commonly accepted that this mode is downshifted by approximately $6 \mathrm{~cm}^{-1}$ transferred to $\mathrm{C}_{60}$ in ionic fulleride compounds. For $\mathrm{C}_{60}$ alkali metals the downshift is directly proportional to the number of metal atoms since each atom donates one electron. The relationship between shift and composition is more complicated for the transition metal fullerides since these compounds may exhibit a large proportion of covalent bonding between metal and $\mathrm{C}_{60}$. The $\mathrm{A}_{\mathrm{g}}(2)$ mode downshift observed for $\mathrm{Pd}-\mathrm{C}_{60}$ and $\mathrm{Pt}-\mathrm{C}_{60}$ fullerides is $15 \mathrm{~cm}^{-1}$, and it suggests that these fullerides have a structure with the metal atoms connected by a $\eta^{2}$-bonding to two neighboring $\mathrm{C}_{60}$ molecules. From the work function of $\mathrm{Ru}(4.71$ $\mathrm{eV}$ ) one would expect a similar spectral shift as for $\mathrm{Cu}(4.70 \mathrm{eV})$ of $-23 \mathrm{~cm}^{-1}$. We observe here a spectral shift as large as -10.1 $\mathrm{cm}^{-1}$ for the $\mathrm{Ru}-\mathrm{C}_{60} 10 / 1$ sample, and a significant broadening with increasing amount of $\mathrm{C}_{60}$ caused by strong electronphonon interaction. For the $\mathrm{Ru}-\mathrm{C}_{60} 1 / 1$ sample, the spectral shift is of $-6 \mathrm{~cm}^{-1}$. The spectrum of $\mathrm{C}_{60}$ without $\mathrm{Ru}$ is shown at the bottom of Fig. 11a for comparison. The fact that the spectra with $\mathrm{Ru}$ do not show a superimposed spectrum of $\mathrm{C}_{60}$, demonstrates that the $\mathrm{C}_{60}$ is strongly interacting with $\mathrm{Ru}$. The $\mathrm{A}_{\mathrm{g}}$ (2) mode downshift difference between the $\mathrm{Ru}-\mathrm{C}_{60}$ and $\mathrm{Pd}-$ $\mathrm{C}_{60}$ and $\mathrm{Pt}-\mathrm{C}_{60}$ fullerides might be due to a different coordination mode: a $\eta^{2}$-bonding to two neighboring $\mathrm{C}_{60}$ for $\mathrm{Pd}-\mathrm{C}_{60}$ and $\mathrm{Pt}-\mathrm{C}_{60}$, and $\eta^{2}$ and $\eta^{6}$ for the $\mathrm{Ru}-\mathrm{C}_{60}$ fulleride. The charge transfer to the $\mathrm{C}_{60}$ molecules is therefore not only dependent on the metal but also on the type of covalent bonds. The charge transfer was also evidenced by XPS, by comparing the binding energy of Ru3p3/2 (462.2 eV) with that of metallic ruthenium $(461.2 \mathrm{eV})$. Fig. 11b shows how the spectral shift progressively saturates at higher molar concentration of $\mathrm{C}_{60}$. No sizeable spectral shifts are observed for the $H_{g}(7)$ and $H_{g}(8)$ modes, which is consistent with only smaller shifts observed for $\mathrm{C}_{60}$ on $\mathrm{Cu}\left(<7 \mathrm{~cm}^{-1}\right)$. The smaller observed spectral shift observed for the $\mathrm{Ru}-\mathrm{C}_{60}$ samples compared to metal surfaces, indicates that the work function of the Ru species is larger than for bulk Ru.

\subsection{WAXS and EXAFS characterization}

Samples sealed in Lindemann glass capillaries were measured by WAXS using a diffractometer dedicated to pair-distribution function (PDF) studies (low background, Mo radiation). For the samples with high $\mathrm{Ru} / \mathrm{C}_{60}$ ratio, the obtained diffractograms are very close and fully consistent with metallic $\mathrm{Ru}$ in the hcp system (Fig. 12a) with no significant contribution of $\mathrm{C}_{60}$. After corrections and Fourier transforms, the related PDF functions are as expected also very close, and consistent with metallic $\mathrm{Ru}$ NPs with low structural disorder and sizes (from coherence length) reaching $2.5 \mathrm{~nm}$. From the shape of the envelope characterized by a rapid initial decrease and a secondary maximum for a larger value ( $c a .1 .5 \mathrm{~nm}$ ) before the final decrease, size dispersion is likely, with a large proportion of NPs much smaller than the $2.5 \mathrm{~nm}$ value. This is in agreement with TEM measurements. Evolution is much different for smaller $\mathrm{Ru} / \mathrm{C}_{60}$ ratios: for $10 / 1,5 / 1$ and $2 / 1$, we first observe (Fig. 12b) a gradual decrease of the peaks characteristic of the $\mathrm{Ru}$ hcp structure, then for the 1/1 ratio the hep crystalline signature totally vanishes and the diffractogram is closer to the one obtained for pure $\mathrm{C}_{60}$, excepted for the sharp peaks at low angle observed only for the highly ordered pure $\mathrm{C}_{60}$ sample. The main

a)

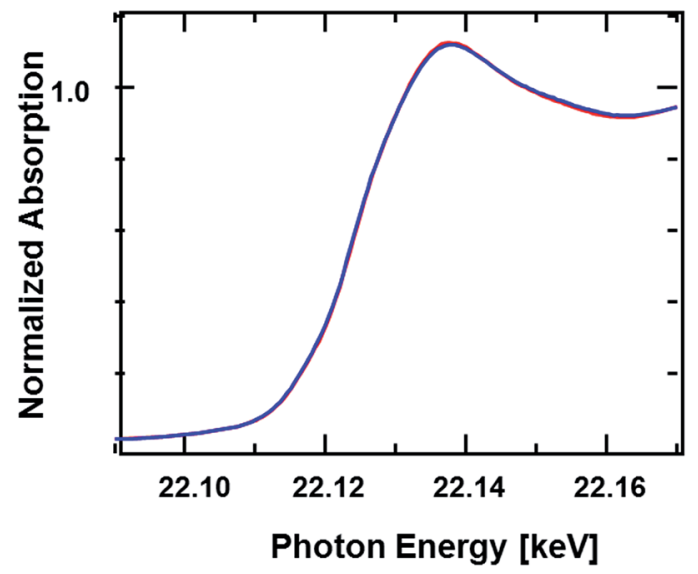

b)
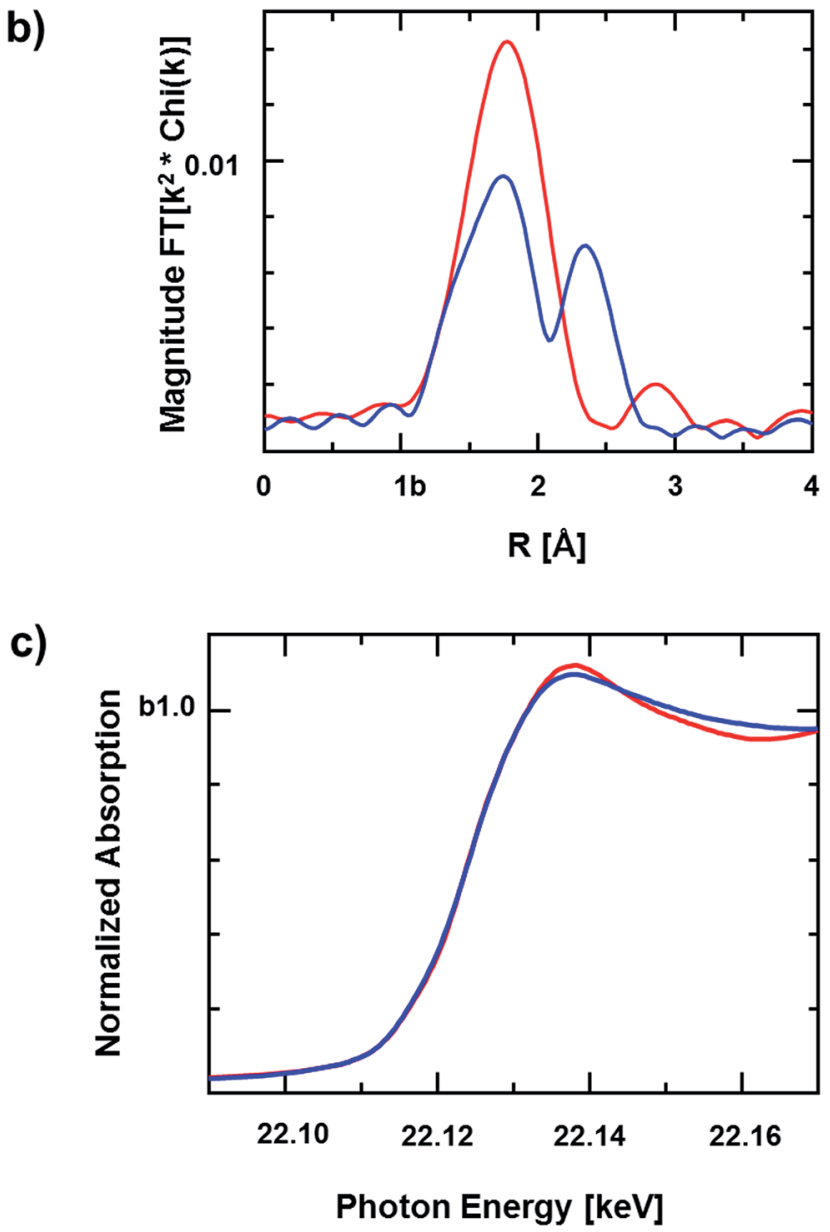

Fig. 13 (a) Ru K-edge XANES from 22.09 to $22.17 \mathrm{keV}$ (red: Ru- $\mathrm{C}_{60} 1 / 1$ $\mathrm{N}_{2}$ at RT, and blue: $\mathrm{Ru}-\mathrm{C}_{60} 1 / 1 \mathrm{H}_{2}$ at $150{ }^{\circ} \mathrm{C}$ ); (b) magnitude of the Fourier transform of $k^{2}$-weighted Ru EXAFS $\left(k^{2}: \Delta k=2.8-11.3 \AA^{-1}\right)$ (blue: $\mathrm{Ru}-\mathrm{C}_{60} 2 / 1, \mathrm{H}_{2}$ at $150{ }^{\circ} \mathrm{C}$, red: $\mathrm{Ru}-\mathrm{C}_{60} 1 / 1, \mathrm{H}_{2}$ at $150{ }^{\circ} \mathrm{C}$ ); and (c) Ru K-edge XANES from 22.09 to $22.17 \mathrm{keV}$ (blue: Ru- $\mathrm{C}_{60} 1 / 1, \mathrm{H}_{2}$ at 150 ${ }^{\circ} \mathrm{C}$ red: $\mathrm{Ru}-\mathrm{C}_{60} 2 / 1, \mathrm{H}_{2}$ at $150{ }^{\circ} \mathrm{C}$ ). 
Table 4 Ruthenium EXAFS fits of samples Ru- $C_{60} 1 / 1$ and 2/1

\begin{tabular}{|c|c|c|c|c|c|c|}
\hline Sample & XANES energy, keV & Scatter & $N$ & $R, \AA$ & $\Delta \sigma^{2}\left(\times 10^{3}\right)$ & $E_{\mathrm{o}}, \mathrm{eV}$ \\
\hline $\mathrm{Ru}$ foil, ref & 22.1170 & $\mathrm{Ru}-\mathrm{Ru}$ & 12 & 2.68 & 0.0 & 8.5 \\
\hline $\mathrm{RuO}_{2}$ & 22.1285 & $\mathrm{Ru}-\mathrm{O}$ & 5.8 & 1.97 & 3.0 & 0.5 \\
\hline $\mathrm{Ru}\left(\mathrm{NH}_{3}\right)_{6} \mathrm{Cl}_{2}$ & 22.1248 & & & & & \\
\hline $\mathrm{Ru}-\mathrm{C}_{60} 1 / 1, \mathrm{~N}_{2}$ at $\mathrm{RT}$ & 22.1244 & $\mathrm{Ru}-\mathrm{C}$ & 8.3 & 2.21 & 3.0 & 7.7 \\
\hline $\mathrm{Ru}-\mathrm{C}_{60} 1 / 1, \mathrm{H}_{2}$ at $150^{\circ} \mathrm{C}$ & 22.1244 & $\mathrm{Ru}-\mathrm{C}$ & 8.3 & 2.21 & 3.0 & 8.7 \\
\hline
\end{tabular}

interest of PDF analysis is the capability to go beyond crystalline order and to analyze characteristic distances in the material, related to crystalline periodicity or not. In the present case, we observe on the PDF a decrease of the metallic Ru order, however mostly marked for the longer distances for the 10/1, 5/1 and 2/1 ratios, actually indicating Ru NPs with a more single size distribution and an average diameter close to $1.5 \mathrm{~nm}$ for the 2/1 ratio. For the 1/1 ratio (ESI.14 $\dagger$ ), we observe a drastic change for the distances in the $0.2-0.3 \mathrm{~nm}$ range: for $2 / 1$, we can still observe the $\mathrm{Ru}-\mathrm{Ru}$ bonding distance $(0.265 \mathrm{~nm}$ in bulk $\mathrm{Ru})$, it however fully vanishes for $1 / 1$, which in this range of distances is indeed very close to pure $\mathrm{C}_{60}$. Distribution of distances in this range may also quite well accommodate bonds between $\mathrm{Ru}$ atoms and light elements, especially $\mathrm{C}$ (the $0.21-0.23 \mathrm{~nm}$ range for the $\mathrm{Ru}-\mathrm{C}$ bonding distance is quite common).

In addition, $a b$ initio calculations, as well as the results of our DFT calculations, show a significant contraction of the bond lengths for $\mathrm{Ru}_{n}$ clusters $(n<13)$ : $\mathrm{Ru}-\mathrm{Ru}$ bonding distance between 0.21 and $0.24 \mathrm{~nm}$. However, since non-bonding C-C distances from $\mathrm{C}_{60}$ obviously also pile up there, such agreement with PDF is however not a clear evidence of $\mathrm{Ru}-\mathrm{C}$ or $\mathrm{Ru}-\mathrm{Ru}$ bonds. All these elements clearly indicate that for the $1 / 1$ ratio, there is no evidence of Ru NPs, although we cannot completely discarded some metallic bonding for Ru atoms in small clusters in this sample. Order is dominated by the $\mathrm{C}_{60}$ structure for short distances, but discrepancies for distances above $0.7 \mathrm{~nm}$ strongly indicate more extended ordering, however difficult to safely characterize. Short distances are also in good agreement with eventual $\mathrm{Ru}-\mathrm{C}$ bonding. For the 2/1 ratio, small Ru NPs ( $c a .1 .5$ $\mathrm{nm}$ ) can be observed. For the 5/1 ratio and above, these small NPs can still be observed but associated to an increasing proportion of larger NPs ( $2.5 \mathrm{~nm}$ from coherence length), which suggests increasing coalescence from small NPs.

EXAFS analyses. The Ru K-edge X-ray absorption spectra of samples $\mathrm{Ru}-\mathrm{C}_{60} 1 / 1$ and $2 / 1$ were obtained in $\mathrm{N}_{2}$ (as synthesized) and after heating in $4 \% \mathrm{H}_{2} / \mathrm{He}$ for $1 \mathrm{~h}$ at $150{ }^{\circ} \mathrm{C}$. The X-ray absorption near edge (XANES) spectra of Ru- $\mathrm{C}_{60} 1 / 1$ in $\mathrm{N}_{2}$ and after high temperature treatment are shown in Fig. 13a. The XANES energy is $22.1244 \mathrm{keV}$ for both spectra and the shape of the XANES does not change after hydrogen treatment indicating no change in the $\mathrm{Ru}$ oxidation state, or structure after high temperature treatment under $\mathrm{H}_{2}$. The magnitude of the Fourier transform of $\mathrm{Ru}-\mathrm{C}_{60} 1 / 1$ after high temperature $\mathrm{H}_{2}$ (Fig. 13b) shows a peak below about $2 \AA$ (phase uncorrected distance) and a small peak at longer distance. The fit of the Fourier transform is given in Table 4 . The low $R$ peak is fit with a $\mathrm{Ru}-\mathrm{C}$ phase and amplitude functions calculated by FEFF, and gives $8.3 \mathrm{Ru}-\mathrm{X}$ bonds at $2.24 \AA$. Typical $\mathrm{Ru}-\mathrm{O}$ bonds are below $2.0 \AA$, while $\mathrm{Ru}-$ $\mathrm{C}$ are longer at about $2.2 \AA$, thus it is likely that the light scatter is $\mathrm{Ru}-\mathrm{C}$. Within the error of the analysis the fits of the sample treated in $\mathrm{H}_{2}$ at $150{ }^{\circ} \mathrm{C}$ is identical to that in $\mathrm{N}_{2}$ at r.t. In both the $\mathrm{N}_{2}$ and $\mathrm{H}_{2}$ spectra there is no indication of $\mathrm{Ru}-\mathrm{Ru}$ scatters typical of metallic Ru NPs. There is a small peak at about $3 \AA$, which is likely due to a $\mathrm{Ru}-\mathrm{C}-\mathrm{Ru}$ scatter; however, the peak is too small to fit reliably. The XANES and magnitude of the Fourier transform of $\mathrm{Ru}-\mathrm{C}_{60} 1 / 1$ and $2 / 1$ heated to $150{ }^{\circ} \mathrm{C}$ in $\mathrm{H}_{2}$ are shown in Fig. $12 \mathrm{c}$ and b, respectively.

The XANES energy of $\mathrm{Ru}-\mathrm{C}_{60} 2 / 1$ is the same as $\mathrm{Ru}-\mathrm{C}_{60} 1 / 1$, e.g., $22.1244 \mathrm{keV}$; however, the shape of the XANES is slightly different, indicating some small difference in structure. The magnitude of the FT of $\mathrm{Ru}-\mathrm{C}_{60} 2 / 1$ shows that there are fewer light scatters and a new higher $R$ peak at about $2.5 \AA$ (phase uncorrected distance). Fits of the EXAFS spectra indicate there are fewer Ru-C, $5.1 \mathrm{Ru}-\mathrm{C}$ at $2.24 \AA$, compared to sample $\mathrm{Ru}-\mathrm{C}_{60}$ $1 / 1$. In addition, the scatter at longer $R$ is due to $\mathrm{Ru}-\mathrm{Ru}$ scatter with a coordination number of 2.2 at $2.63 \AA$, typical of metallic $\mathrm{Ru}$ NPs. Since non-metallic Ru-C has 8 bonds, a coordination number of 5.1 indicates that approximately $61 \%$ of the $\mathrm{Ru}$ is bonded to $\mathrm{C}$ in the $\mathrm{Ru}-\mathrm{C}_{60} 2 / 1$ sample. The remaining $\mathrm{Ru}$ is, therefore, metallic, i.e., $39 \%$. For the metallic fraction the true coordination number is the measured coordination number divided by the fraction of metallic Ru, or 2.2/0.39, or 5.6. For fcc and hep metals a coordination number of 5.6 is consistent with a particle size of about $1.5 \mathrm{~nm} .{ }^{82}$ In summary, sample $\mathrm{Ru}-\mathrm{C}_{60} 1 / 1$ has $8 \mathrm{Ru}-\mathrm{C}$ bonds, which are stable to reduction in $\mathrm{H}_{2}$ at $150^{\circ} \mathrm{C}$; while in sample $\mathrm{Ru}-\mathrm{C}_{60} 2 / 1$ approximately one-third of the $\mathrm{Ru}$ is reduced to $1.5 \mathrm{~nm}$ metallic Ru NPs. In the latter, the remaining two-thirds $\mathrm{Ru}-\mathrm{C}$ are identical to those in $\mathrm{Ru}-\mathrm{C}_{60} 1 / 1$ sample.

\section{Conclusions}

In summary, the decomposition reaction of $[\mathrm{Ru}(\mathrm{COD})(\mathrm{COT})]$ in the presence of $\mathrm{C}_{60}$ has been investigated, and the product(s) of the reaction characterized. The choice of the solvent affects the course of the reaction. Spherical particles are selectively produced in solvent with low viscosity and high permittivity, such as dichloromethane. The particle size depends on the nature of the solvent. According to the $\mathrm{Ru} / \mathrm{C}_{60}$ ratio, these 
spherical particles can be surface decorated with metallic $\mathrm{Ru}$ NPs (1.5-2.5 nm), which are stabilized by $\mathrm{C}_{60}$. The structure of the spherical particles has been studied. TEM, EXAFS, WAXS, and DFT calculations point to a polymeric structure, in which each $\mathrm{Ru}$ atoms is coordinated to two $\mathrm{C}_{60}$, with a $\eta^{2(6)}-\eta^{6}$ coordination mode. Solvent molecules contribute to stabilize this fulleride. This polymeric phase is the kinetic product of the reaction. Then, larger $\mathrm{Ru}$ NPs are created on their surface, producing the thermodynamic products of the reaction. During the decomposition reaction under hydrogen, partial hydrogenation of the fullerene occurs, catalysed by the ruthenium. Significant charge transfer from ruthenium to fullerene has been evidenced by Raman spectrometry and XPS for all the prepared materials, which is an important factor to take into account, particularly if we consider the possible reactivity of this fulleride. We believe that these results should open the possibility to draw structure/properties relationships.

\section{Acknowledgements}

This work was supported by the Centre National de la Recherche Scientifique (CNRS), which we gratefully acknowledge. The authors acknowledge financial support from the program of China Scholarships Council (CSC) for F. L. grant. I. C. Gerber also acknowledges the Calcul en Midi-Pyrénées initiativeCALMIP (Project p0812) for allocations of computer time. Part of this work was also performed using HPC resources from GENCI-IDRIS and CINES (Project x2015096649).

\section{References}

1 F. Giacalone, N. Martín and F. Wudl, in Fullerene Polymers, Wiley-VCH Verlag GmbH \& Co. KGaA, 2009, pp. 1-14.

2 B. Coq, J. Marc Planeix and V. Brotons, Appl. Catal., A, 1998, 173, 175-183.

3 N. F. Goldshleger, Fullerene Sci. Technol., 2001, 9, 255-280.

4 B. Machado and P. Serp, in Nanostructured Carbon Materials for Catalysis, The Royal Society of Chemistry, 2015, pp. 312411.

5 R. Loutfy and S. Katagiri, in Perspectives of Fullerene Nanotechnology, ed. E. Ōsawa, Springer, Netherlands, 2002, ch. 32, pp. 357-367.

6 B. S. Sherigara, W. Kutner and F. D'Souza, Electroanalysis, 2003, 15, 753-772.

7 C. Brosseau, Surf. Coat. Technol., 2011, 206, 753-758.

8 M. J. Rosseinsky, Chem. Mater., 1998, 10, 2665-2685.

9 M. Riccò, T. Shiroka, M. Belli, D. Pontiroli, M. Pagliari, G. Ruani, D. Palles, S. Margadonna and M. Tomaselli, Phys. Rev. B: Condens. Matter Mater. Phys., 2005, 72, 155437.

10 V. N. Ivanova, J. Struct. Chem., 2000, 41, 135-148.

11 M. J. Rosseinsky, J. Mater. Chem., 1995, 5, 1497-1513.

12 T. Yildirim, O. Zhou and J. E. Fischer, in The Physics of Fullerene-Based and Fullerene-Related Materials, ed. W. Andreoni, Springer, Netherlands, 2000, vol. 23, ch. 2, pp. 23-66.

13 H. Nagashima, A. Nakaoka, Y. Saito, M. Kato, T. Kawanishi and K. Itoh, J. Chem. Soc., Chem. Commun., 1992, 377-379.
14 K. Winkler, K. Noworyta, W. Kutner and A. L. Balch, J. Electrochem. Soc., 2000, 147, 2597-2603.

15 L. Norin, U. Jansson, C. Dyer, P. Jacobsson and S. McGinnis, Chem. Mater., 1998, 10, 1184-1190.

16 G. H. M. Dias, Quim. Nova, 1995, 18, 592-596.

17 V. Lavrentiev, H. Abe, S. Yamamoto, H. Naramotoand and

K. Narumi, Mol. Cryst. Liq. Cryst., 2002, 386, 139-143.

18 M. Wohlers, B. Herzog, T. Belz, A. Bauer, T. Braun, T. Rühle and R. Schlögl, Synth. Met., 1996, 77, 55-58.

19 A. V. Talyzin and U. Jansson, Thin Solid Films, 2003, 429, 96101.

20 A. S. Gurav, Z. Duan, L. Wang, M. J. Hampden-Smith and T. T. Kodas, Chem. Mater., 1993, 5, 214-216.

21 J. M. Cowley, M. Q. Liu, B. L. Ramakrishna, T. S. Peace, A. K. Wertsching and M. R. Pena, Carbon, 1994, 32, 746-748.

22 A. V. Talyzin, A. Dzwilewski and M. Pudelko, Carbon, 2007, 45, 2564-2569.

23 K. Winkler, K. Noworyta, A. de Bettencourt-Dias, J. W. Sobczak, C.-T. Wu, L.-C. Chen, W. Kutner and A. L. Balch, J. Mater. Chem., 2003, 13, 518-525.

24 T. Braun, M. Wohlers, T. Belz, G. Nowitzke, G. Wortmann, Y. Uchida, N. Pfänder and R. Schlögl, Catal. Lett., 1997, 43, 167-173.

25 V. Lavrentiev, H. Abe, H. Naramoto, S. Sakai and K. Narumi, Chem. Phys. Lett., 2006, 424, 101-104.

26 D. Östling and A. Rosén, Chem. Phys. Lett., 1993, 202, 389393.

27 J. Roques, F. Calvo, F. Spiegelman and C. Mijoule, Phys. Rev. B: Condens. Matter Mater. Phys., 2003, 68, 205412.

28 J. Pitarch-Ruiz, S. Evangelisti and D. Maynau, J. Mol. Struct.: THEOCHEM, 2004, 681, 203-207.

29 L. M. Ramaniah and M. Boero, J. Chem. Phys., 2010, 133, 134701.

30 A. N. Andriotis, M. Menon and G. E. Froudakis, Phys. Rev. B: Condens. Matter Mater. Phys., 2000, 62, 9867-9871.

31 A. N. Andriotis and M. Menon, Phys. Rev. B: Condens. Matter Mater. Phys., 1999, 60, 4521-4524.

32 M. K. Shukla, M. Dubey and J. Leszczynski, ACS Nano, 2008, 2, 227-234.

33 Q. Zeng, X. Chu, M. Yang and D.-Y. Wu, Chem. Phys., 2012, 395, 82-86.

34 L. M. Ramaniah, M. Boero and M. Laghate, Phys. Rev. B: Condens. Matter Mater. Phys., 2004, 70, 035411.

35 M. Matsubara, C. Massobrio, L. M. Ramaniah, E. Ruiz and M. Boero, Phys. Rev. B: Condens. Matter Mater. Phys., 2010, 81, 195433.

36 O. Loboda, Quantum-chemical studies on Porphyrins, Fullerenes and Carbon Nanostructures, Carbon Nanostructures, Springer-Verlag Berlin, Heidelberg, 2013.

37 J. R. Kremer, D. N. Mastronarde and J. R. McIntosh, J. Struct. Biol., 1996, 116, 71-76.

38 C. MessaoudiI, T. Boudier, C. O. S. Sorzano and S. Marco, BMC Bioinf., 2007, 8, 288.

39 G. Kresse and J. Furthmüller, Comput. Mater. Sci., 1996, 6, $15-50$.

40 G. Kresse and J. Hafner, Phys. Rev. B: Condens. Matter Mater. Phys., 1993, 47, 558-561. 
41 G. Kresse and J. Furthmüller, Phys. Rev. B: Condens. Matter Mater. Phys., 1996, 54, 11169-11186.

42 G. Kresse and J. Hafner, Phys. Rev. B: Condens. Matter Mater. Phys., 1994, 49, 14251-14269.

43 P. E. Blöchl, Phys. Rev. B: Condens. Matter Mater. Phys., 1994, 50, 17953-17979.

44 G. Kresse and D. Joubert, Phys. Rev. B: Condens. Matter Mater. Phys., 1999, 59, 1758-1775.

45 J. P. Perdew, K. Burke and M. Ernzerhof, Phys. Rev. Lett., 1996, 77, 3865-3868.

46 M. Dion, H. Rydberg, E. Schröder, D. C. Langreth and B. I. Lundqvist, Phys. Rev. Lett., 2004, 92, 246401.

47 G. Román-Pérez and J. M. Soler, Phys. Rev. Lett., 2009, 103, 096102.

48 J. Kliměs, D. R. Bowler and A. Michaelides, Phys. Rev. B: Condens. Matter Mater. Phys., 2011, 83, 195131.

49 K. Jiřri, R. B. David and M. Angelos, J. Phys.: Condens. Matter, 2010, 22, 022201.

50 K. Momma and F. Izumi, J. Appl. Crystallogr., 2011, 44, 12721276.

51 C. Amiens, B. Chaudret, D. Ciuculescu-Pradines, V. Colliere, K. Fajerwerg, P. Fau, M. Kahn, A. Maisonnat, K. Soulantica and K. Philippot, New J. Chem., 2013, 37, 3374-3401.

52 C. Vauthier and K. Bouchemal, Pharm. Res., 2009, 26, 10251058.

53 C. Mabille, F. Leal-Calderon, J. Bibette and V. Schmitt, Europhys. Lett., 2003, 61, 708-714.

54 V. Schmitt, F. Leal-Calderon and J. Bibette, Top. Curr. Chem., 2003, 227, 195-215.

55 S. K. Smoukov, T. Tian, N. Vitchuli, S. Gangwal, P. Geisen, M. Wright, E. Shim, M. Marquez, J. Fowler and O. D. Velev, Adv. Mater., 2015, 27, 2642-2647.

56 CRC Handbook of Chemistry and Physics, ed. W. M. Haynes, CRC Press, 95th edn, 2014.

57 R. S. Ruoff, D. S. Tse, R. Malhotra and D. C. Lorents, J. Phys. Chem., 1993, 97, 3379-3383.

58 E. Grądzka, M. Wysocka-Żołopa and K. Winkler, J. Phys. Chem. C, 2014, 118, 14061-14072.

59 M. R. Axet, O. Dechy-Cabaret, J. Durand, M. Gouygou and P. Serp, Coord. Chem. Rev., 2016, 308, 236-345.

60 P. J. Fagan, J. C. Calabrese and B. Malone, Science, 1991, 252, 1160-1161.

61 H. Nagashima, Y. Kato, H. Yamaguchi, E. Kimura, T. Kawanishi, M. Kato, Y. Saito, M. Haga and K. Itoh, Chem. Lett., 1994, 23, 1207-1210.

62 A. A. Voityuk, J. Phys. Chem. A, 2009, 113, 11801-11808.

63 Y. Huang and B. S. Freiser, J. Am. Chem. Soc., 1991, 113, 8186-8187.

64 A. D. Darwish, A. G. Avent, R. Taylor and D. R. M. Walton, J. Chem. Soc., Perkin Trans. 2, 1996, 2051-2054.
65 R. Bini, J. Ebenhoch, M. Fanti, P. W. Fowler, S. Leach, G. Orlandi, C. Ruchardt, J. P. B. Sandall and F. Zerbetto, Chem. Phys., 1998, 232, 75-94.

66 A. V. Talyzin, Y. O. Tsybin, T. M. Schaub, P. Mauron, Y. M. Shulga, A. Zuettel, B. Sundqvist and A. G. Marshall, J. Phys. Chem. B, 2005, 109, 12742-12747.

67 A. V. Talyzin, Y. O. Tsybin, J. M. Purcell, T. M. Schaub, Y. M. Shulga, D. Noreus, T. Sato, A. Dzwilewski, B. Sundqvist and A. G. Marshall, J. Phys. Chem. A, 2006, 110, 8528-8534.

68 R. Ghafouri and M. Anafcheh, Fullerenes, Nanotubes, Carbon Nanostruct., 2015, 23, 40-48.

69 S. M. C. Vieira, W. Ahmed, P. R. Birkett, C. A. Rego, S. Kotsiris and T. Drewello, Fullerenes, Nanotubes, Carbon Nanostruct., 2004, 12, 139-145.

70 T. Wagberg, D. Johnels, A. Peera, M. Hedenstroem, Y. M. Schulga, Y. O. Tsybin, J. M. Purcell, A. G. Marshall, D. Noreus, T. Sato and A. V. Talyzin, Org. Lett., 2005, 7, 5557-5560.

71 R. E. Haufler, J. Conceicao, L. P. F. Chibante, Y. Chai, N. E. Byrne, S. Flanagan, M. M. Haley, S. C. O'Brien, C. Pan, et al., J. Phys. Chem., 1990, 94, 8634-8636.

72 A. S. Lobach, Y. M. Shul'ga, O. S. Roshchupkina, A. I. Rebrov, A. A. Perov, Y. G. Morozov, V. N. Spector and A. A. Ovchinnikov, Fullerene Sci. Technol., 1998, 6, 375-391.

73 S. M. Luzan, Y. O. Tsybin and A. V. Talyzin, J. Phys. Chem. C, 2011, 115, 11484-11492.

74 A. V. Talyzin, Y. M. Shulga and A. Jacob, Appl. Phys. A: Mater. Sci. Process., 2004, 78, 1005-1010.

75 L. Becker, T. P. Evans and J. L. Bada, J. Org. Chem., 1993, 58, 7630-7631.

76 Y. M. Wuu, J. G. Bentsen, C. G. Brinkley and M. S. Wrighton, Inorg. Chem., 1987, 26, 530-540.

77 Y. M. Wuu, C. Zou and M. S. Wrighton, Inorg. Chem., 1988, 27, 3039-3044.

78 S. L. Ingham and S. W. Magennis, J. Organomet. Chem., 1999, 574, 302-310.

79 P. Lara, T. Ayvali, M.-J. Casanove, P. Lecante, A. Mayoral, P.-F. Fazzini, K. Philippot and B. Chaudret, Dalton Trans., 2013, 42, 372-382.

80 X. Qi, M. R. Axet, K. Philippot, P. Lecante and P. Serp, Dalton Trans., 2014, 43, 9283-9295.

81 S. J. Chase, W. S. Bacsa, M. G. Mitch, L. J. Pilione and J. S. Lannin, Phys. Rev. B: Condens. Matter Mater. Phys., 1992, 46, 7873-7877.

82 J. T. Miller, A. J. Kropf, Y. Zha, J. R. Regalbuto, L. Delannoy, C. Louis, E. Bus and J. A. van Bokhoven, J. Catal., 2006, 240, 222-234. 